\title{
Orchidaceae no município de Caldas Novas, Goiás, Brasil
}

\author{
Orchidaceae of Caldas Novas, state of Goiás, Brazil
}

\author{
Climbiê Ferreira Hall ${ }^{1,3}$, Vera Lúcia Gomes Klein ${ }^{2}$ \& Fábio de Barros ${ }^{1}$
}

\begin{abstract}
Resumo
O presente estudo teve como objetivo inventariar as espécies de Orchidaceae ocorrentes no município de Caldas Novas. Para tanto, foram realizadas coletas mensais, durante o ano de 2008 (exceto entre setembro e novembro). Paralelamente aos trabalhos de campo foram realizados levantamentos nos herbários CEN, IBGE, UB e UFG. São apresentados chave de identificação, descrições morfológicas, comentários e ilustrações das espécies. Foram registrados 15 gêneros e 28 espécies de Orchidaceae na área. Os gêneros que apresentaram maior número de espécies foram Epidendrum e Habenaria (seis espécies cada), seguidos por Cleistes (três), e Cyrtopodium (duas). Cinco espécies listadas são novas ocorrências para Goiás, mostrando a necessidade de inventários florísticos no estado.
\end{abstract}

Palavras-chave: Cerrado, florística, orquídea, taxonomia.

\begin{abstract}
The aim of this study was to inventory the species of Orchidaceae occurring in Caldas Novas. We conducted monthly collections during 2008 (except from September to November). Parallel to the fieldwork, surveys were done in the herbaria CEN, IBGE, UB and UFG. We present an identification key, morphological descriptions, comments and illustrations of the species. We recorded 15 genera and 28 species of Orchidaceae in the area. The genera with more species were Epidendrum and Habenaria (six species each), followed by Cleistes (three), and Cyrtopodium (two). Five species are new records for the state of Goiás, showing that floristic inventories in the state are still needed.
\end{abstract}

Keywords: "Cerrado", floristics, orchids, taxonomy.

\section{Introdução}

O Cerrado é um dos hotspots mundiais de diversidade (Myers et al. 2000) e constitui o segundo maior domínio fitogeográfico do Brasil e da América do Sul, ocupando cerca de 2 milhões de $\mathrm{km}^{2}$, que corresponde a aproximadamente a $25 \%$ do território brasileiro (Dias 1992). Esse domínio abrange o Distrito Federal e quase todo o território dos estados de Goiás e Tocantins, além de partes da Bahia, Ceará, Maranhão, Mato Grosso, Mato Grosso do Sul, Minas Gerais, Paraná, Piauí, Rondônia, São Paulo e algumas manchas na região amazônica.

Segundo Barros et al. (2013), o Cerrado possui cerca de 680 espécies de Orchidaceae, o que a torna uma das famílias mais representativas em número de espécies, embora não componha um elemento dominante da vegetação local. Apesar da importância florística da família no Cerrado, poucos trabalhos são destinados ao levantamento de suas espécies.

O Distrito Federal, até o momento, é a área mais bem amostrada (e.g., Pereira et al. 1993; Filgueiras \& Pereira 1994; Batista \& Bianchetti 2003; Batista et al. 2005; Bianchetti et al. 2005), e, de acordo com os dados disponíveis atualmente, possui mais espécies de orquídeas registradas do que Goiás e Tocantins somados (Bianchetti et al. 2005). Independentemente da real diversidade local da família isso demonstra o quão pequeno ainda é o esforço de coleta realizado no Cerrado e a importância do desenvolvimento de inventários

\footnotetext{
${ }^{1}$ Instituto de Botânica, Núcleo de Pesquisa Orquidário do Estado, C.P. 68041, 04045-972, São Paulo, SP, Brasil.

${ }^{2}$ Universidade Federal de Goiás, Inst. Ciências Biológicas, Depto. Biologia Geral, Lab. Morfologia e Taxonomia Vegetal, C.P. 131, 74001-970, Campus Samambaia, Goiânia, GO, Brasil.

${ }^{3}$ Autor para correspondência: climbiehall@yahoo.com.br
} 
florísticos. No caso de Caldas Novas, poucos são os estudos florísticos na região e, ainda assim, focados no estrato arbustivo-arbóreo (e.g., Silva et al. 2002; Lima et al. 2010).

Por sua beleza e exotismo, as orquídeas são utilizadas como plantas ornamentais, sendo comumente retiradas de seus ambientes naturais e, posteriormente, comercializadas. Essa prática extrativista, somada aos problemas enfrentados pelo Cerrado, como a destruição dos hábitats pelo desmatamento, deixa muitas espécies em risco de extinção (Klink \& Machado 2005). Neste sentido, informações sobre a distribuição das espécies, sua biologia e hábitats naturais subsidiam esforços de conservação das espécies in situ, circunscrevendo as áreas de maior diversidade e as áreas onde são encontradas espécies raras, endêmicas ou ameaçadas de extinção. O objetivo do presente estudo é apresentar um inventário das espécies da família Orchidaceae ocorrentes no município de Caldas Novas, incluindo descrições morfológicas, comentários, chave para identificação das espécies e ilustrações.

\section{Material e Métodos}

O município de Caldas Novas está localizado no sudeste do estado de Goiás e possui apenas uma Unidade de Conservação (UC), o Parque Estadual da Serra de Caldas Novas (PESCAN), que resguarda em sua área os remanescentes de vegetação em melhor estado de conservação do município, de modo que o trabalho de campo foi concentrado na área da UC.

O PESCAN compreende uma área de cerca de 12.500 ha, destacando-se um platô no topo constituído principalmente por cerrado sensu stricto, vegetação predominante no município (SIEG 2012). As laterais do platô são formadas por encostas contendo áreas de vegetação rupestre e campos úmidos, e a base, que faz divisa com fazendas e loteamentos urbanos, possui áreas de mata de galeria (Rizzo 1981; Lima et al. 2010). A altitude no platô da serra é de cerca de 1.043 m (Iglesias et al. 2011). A região apresenta duas estações bem definidas, uma chuvosa, entre os meses de novembro e março, e outra seca, de maio a setembro, características que enquadram o clima da região no tipo Aw (Köppen, 1948).

Durante o ano de 2008, foram realizadas coletas mensais, com duração média de três dias cada, em diferentes pontos do PESCAN. As áreas do parque foram percorridas de forma não sistematizada, buscando-se cobrir a maior extensão possível e as diferentes fitofisionomias em cada expedição. Entre os meses de setembro e novembro não foram realizadas coletas em virtude da ocorrência de uma queimada no parque, que impossibilitou a realização de expedições à área.

A coleta e a herborização do material foram realizadas de acordo com as técnicas usuais (Mori et al. 1989). Cartões com as peças florais distendidas, oriundas dos diferentes espécimes, foram montados para facilitar o estudo morfológico e taxonômico. As identificações foram realizadas através de consultas às obras específicas da família, como: Rodrigues (1877, 1882), Cogniaux (1893-1896, 1898-1902, 1904-1906), Hoehne (1940, 1942, 1945, 1949, 1953), Pabst \& Dungs (1975, 1977) e Sprunger et al. (1996), além de trabalhos específicos de cada gênero (e.g., Batista \& Bianchetti 2002) e comparação com coleções depositadas nos herbários SP e UFG, acrônimos segundo Thiers (2013). As informações sobre forma de vida e hábitat dos espécimes foram obtidas durante os trabalhos de campo ou das etiquetas dos exemplares depositados nos herbários. A altura apresentada nas descrições das plantas é sempre a maior altura alcançada, independentemente do órgão (e.g. caule, inflorescência, etc.). Os espécimes coletados foram incorporados ao herbário UFG. A atualização dos nomes científicos está de acordo com a Lista das Espécies da Flora do Brasil (Barros et al. 2013).

Paralelamente ao trabalho de campo, foi realizado um levantamento dos exemplares da família nos herbários CEN, IBGE, UB e UFG, acrônimos segundo Thiers (2013), e todas as espécies citadas para Caldas Novas foram incorporadas ao estudo.

\section{Resultados e Discussão}

Foram registrados 15 gêneros e 28 espécies de Orchidaceae em Caldas Novas. Os gêneros que apresentaram maior número de espécies foram Epidendrum L. e Habenaria Willd. (6 spp.), seguidos por Cleistes Rich. ex Lindl. (3 spp.) e Cyrtopodium Lindl. (2 spp.). Três espécies pertencentes aos gêneros Catasetum Rich. ex Kunth, Galeandra Lindl. e Polystachya Hook. foram vistas apenas em estado estéril no PESCAN, de modo que não foram tratadas no trabalho. Foram registradas 12 espécies de Orchidaceae no PESCAN (excetuando-se as que foram observadas apenas em estado estéril). Para nove delas não havia registro prévio em herbário para o município. 
A maioria das espécies de Orchidaceae encontradas em Caldas Novas possui ampla distribuição, sendo apenas oito espécies endêmicas do Brasil: Cleistes mantiqueirae (Rchb. f. \& Warm.) Schltr.; Cleistes paranaensis (Barb. Rodr.) Schltr.; Epidendrum amblostomoides Hoehne; Galeandra Montana Barb. Rodr.; Habenaria glaucophylla Barb. Rodr.; Habenaria lavrensis Hoehne; Notylia hemitricha Barb. Rodr. e Orleanesia mineirosensis Garay. Mesmo dentre as endêmicas do Brasil, apenas duas espécies possuem distribuição mais restrita, $H$. lavrensis e $O$. mineirosensis, sendo a última a única espécie endêmica de Goiás encontrada na área de estudo. Também para o domínio do Cerrado, poucas são as espécies endêmicas, apenas: Cyrtopodium paludicolum
Hoehne, H. lavrensis e O. mineirosensis (Barros et al. 2013).

A maior parte dos espécimes encontrados nos herbários é advinda de um trabalho de resgate de flora realizado na época de formação do Lago Corumbá, resultante do represamento do Rio Corumbá. O levantamento dos espécimes registrados em herbários foi importante, pois cinco espécies do presente estudo não estão citadas para o estado de Goiás na Lista de Espécies da Flora do Brasil (Barros et al. 2013), referidas a seguir: Bulbophyllum exaltatum Lindl., Epidendrum pseudodifforme Hoehne \& Schltr., Epidendrum rigidum Jacq., H. lavrensis e $N$. hemitricha. Essas novas ocorrências demonstram a necessidade de realização de mais inventários florísticos em Goiás.

\section{Chave para identificação das espécies de Orchidaceae no município de Caldas}

1. Cauloma intumescido em pseudobulbo.

2. Pseudobulbos sobrepostos (novos pseudobulbos crescendo no ápice dos anteriores)

2'. Pseudobulbos não sobrepostos.

3. Inflorescência terminal.

4. Planta terrícola; flor calcarada 16. Galeandra montana

4'. Planta epífita; flor não calcarada.

5. Pseudobulbos uni ou bifoliados 8. Encyclia argentinensis

5'. Pseudobulbos multifoliados.

6. Flores alvo-esverdeadas; labelo com unguículo adnato ao ginostêmio 9. Epidendrum amblostomoides

6'. Flores creme-esverdeadas; labelo livre do ginostêmio 26. Orleanesia mineirosensis

3'. Inflorescência lateral.

7. Folhas plicadas.

8. Pseudobulbos ca. $2 \mathrm{~cm}$ compr., piriformes, unifoliados; flores alvas com máculas vinosas 23. Koellensteinia tricolor

8'. Pseudobulbos 15,5-20 cm compr., fusiformes, multifoliados; flores amarelas com máculas castanhas ou vermelhas.

9. Flores com pétalas e sépalas amarelo-pálidas com máculas castanhas; labelo ca. 1,8 $\times 1,6 \mathrm{~cm}$, amarelo-vivo com lobos laterais castanhos

6. Cyrtopodium eugenii

9'. Flores com pétalas e sépalas amarelas; labelo ca. 2,2 × 3,5 cm, amarelo com máculas vermelhas nos lobos laterais e no calo

7. Cyrtopodium paludicolum

7'. Folhas conduplicadas.

10. Folhas verde-claras, maculadas de verde-escuro; flores calcaradas

10. Folhas não maculadas; flores ecalcaradas. 25. Oeceoclades maculata

11. Pseudobulbos ovoides, rômbicos em corte transversal; folhas oblongas; flores verdes com máculas castanhas 1. Bulbophyllum exaltatum

11'. Pseudobulbos elipsoides ou piriformes, ovoides a arredondados em corte transversal; folhas lineares ou elípticas; flores alvas ou verdes com máculas alaranjadas. 
12. Folhas lineares; inflorescência em fascículo; flores alvas

2. Camaridium ochroleucum

12'. Folhas elípticas a estreito-elípticas; inflorescência em racemo; flores verdes com máculas alaranjadas

24. Notylia hemitricha

1'. Cauloma ou caule não intumescido em pseudobulbo.

13. Flores calcaradas.

14. Folhas rosuladas na base da planta

17. Habenaria glaucophylla

14'. Folhas espiraladas ao longo do caule.

15. Labelo inteiro.

16. Pétalas bipartidas, segmento superior triangular-lanceolado, segmento inferior reduzido a um pequeno dente

20. Habenaria obtusa

16'. Pétalas inteiras, sub-quadrangulares, ápice truncado ..... 21. Habenaria petalodes

15'. Labelo trífido.

17. Sépala dorsal com ápice longo-acuminado a caudado .... 18. Habenaria lavrensis

17'. Sépala dorsal com ápice agudo a obtuso.

18. Inflorescência 9-10 cm compr.; labelo ca. $7 \mathrm{~mm}$ compr.; calcar ca. $1,3 \mathrm{~cm}$ compr.

22. Habenaria secundiflora

18'. Inflorescência 5,5-7 cm compr.; labelo ca. 5 mm compr.; calcar ca. $9 \mathrm{~mm}$ compr.

19. Habenaria leprieuri

13'. Flores ecalcaradas.

19. Folhas rosuladas na base da planta; flores sésseis; labelo calceolado

27. Prescottia oligantha

19'. Folhas dísticas ou espiraladas ao longo do caule; flores pediceladas; labelo não calceolado.

20. Folhas dísticas; flores amarelo-esverdeadas, alvo-esverdeadas ou verdes; labelo adnato ao ginostêmio.

21. Planta terrícola; inflorescência em panícula (raramente racemo)

22. Caule ramificado; flores amarelo-esverdeadas; labelo inteiro, conduplicado

10. Epidendrum dendrobioides

22'. Caule simples; flores alvo-esverdeadas; labelo trilobado, plano

11. Epidendrum densiflorum

21'. Planta epífita; inflorescência em racemo.

23. Caule ramificado, pendente; flores alvo-esverdeadas

14. Epidendrum strobiliferum

23'. Caule não ramificado, ereto; flores verdes.

24. Inflorescência 6-13 cm compr.; pedicelo e ovário encobertos pelas brácteas florais, brácteas florais cimbiformes de base imbricante; labelo inteiro, ápice obtuso

13. Epidendrum rigidum

24'. Inflorescência 3-4 cm compr.; pedicelo e ovário não encobertos pelas brácteas; labelo trilobado a inteiro, ápice emarginado

12. Epidendrum pseudodifforme

20'. Folhas espiraladas; flores róseas a lilases; labelo não adnato ao ginostêmio

25. Raízes sem tuberoides; folhas coriáceas, nervação reticulada; flores com calículo no ápice do ovário

15. Epistephium sclerophyllum

25'. Raízes com tuberoides; folhas cartáceas, nervação paralelinérvea; flores sem calículo no ápice do ovário.

26. Flores lilases; labelo púrpura, com crista formada por fímbrias

5. Cleistes paranaensis

26'. Flores róseas; labelo róseo ou púrpura, com crista formada por papilas.

27. Planta ca. $60 \mathrm{~cm}$ alt.; a maior folha ca. $5,5 \times 1 \mathrm{~cm}$; labelo róseo, ca. 2,8 $\times 0,6 \mathrm{~cm}$, trilobado

4. Cleistes mantiqueirae

27'. Planta 65-140 cm alt.; a maior folha ca. $14 \times 4 \mathrm{~cm}$; labelo púrpura, 6,5-7 $\times 2,4-2,7 \mathrm{~cm}$, inteiro 3. Cleistes grandiflora 
1. Bulbophyllum exaltatum Lindl., Ann. Mag. Nat. Hist. 10: 186. 1842.

Fig. 1a

Epífita, 31-50,5 cm alt. Cauloma intumescido em pseudobulbo; pseudobulbos amarelados, 2,2$3,1 \mathrm{~cm}$ compr., ovoides, transversalmente rômbicos, unifoliados. Folhas coriáceas, conduplicadas, 3,9-6,7 × 1,3-2 cm, oblongas, ápice obtuso. Inflorescência em racemo, lateral, $31-50,5 \mathrm{~cm}$ compr., multiflora, ereta, laxa. Flores verdes com máculas castanhas, ressupinadas, pediceladas, ecalcaradas; sépala dorsal ca. $10 \times 3-4,5 \mathrm{~mm}$, oblongo-lanceolada a ovada, ápice agudo; sépalas laterais ca. $10 \times 3-4 \mathrm{~mm}$, ovadas, levemente assimétricas, ápice agudo; pétalas ca. $3 \times 4 \mathrm{~mm}$, triangulares, ápice agudo; labelo púrpura, 5,5-6× 2,5-3 mm, trilobado, lobo mediano 4-4,5 $\times 2 \mathrm{~mm}$, lobos laterais ca. $1 \times 1 \mathrm{~mm}$; ginostêmio creme, ca. 2,5 mm compr., estelídias presentes.

Material examinado: bacia de inundação do AHE Corumbá, 2.X.1996, fr., T.B. Cavalcanti et al. 2088 (CEN, SP).

Material adicional examinado: BRASIL. MINAS GERAIS: Itutinga, 19.I.1981, fl., F. Barros 604 (SP); Serra do Caraça, 18.I.1921, fl., F.C. Hoehne (SP5049);

Bulbophyllum exaltatum está distribuído pelo Brasil, Bolívia, Colômbia, Peru e Venezuela. No Brasil ocorre na Bahia, Espírito Santo, Goiás, Minas Gerais, Santa Catarina e São Paulo (Smidt 2007; Barros et al. 2013). Espécie coletada na copa das árvores da Bacia de inundação da AHE Corumbá, hábito que se diferencia do que normalmente ocorre com a espécie, que é tipicamente rupícola. Floresce entre dezembro e abril (Smidt 2007). Bulbophyllum exaltatum pode ser diferenciado das outras espécies de orquídeas ocorrentes na região estudada pelos pseudobulbos rômbicos em corte transversal e amarelados, e pelas flores verdes com máculas castanhas.

2. Camaridium ochroleucum Lindl., Bot. Reg. 10: 844. 1824.

Fig. 1b

Epífita, $19-30 \mathrm{~cm}$ alt. Cauloma intumescido em pseudobulbo; pseudobulbos 3-3,5 cm compr., elipsoides, transversalmente ovoides, lateralmente compressos, uni ou bifoliados. Folhas coriáceas, conduplicadas, $16-26,5 \times 1,1-1,3 \mathrm{~cm}$, lineares, ápice obtuso. Inflorescência em fascículo, lateral, 3,5-5,4 cm compr., pauciflora, ereta, laxa. Flores alvas, ressupinadas, pediceladas, ecalcaradas; sépala dorsal $2,5-2,9 \times 0,8-0,9 \mathrm{~cm}$, elípticoobovada, ápice agudo; sépalas laterais 2,4-2,9 $\times 1-1,2 \mathrm{~cm}$, obovadas, levemente assimétricas, ápice agudo; pétalas $2,1-2,9 \times 0,7-0,8 \mathrm{~cm}$, oblanceoladas, ápice agudo; labelo 1,2-1,3 × $1,1-1,3 \mathrm{~cm}$, trilobado; lobo mediano ca. $6 \times 8 \mathrm{~mm}$, suborbicular, ápice retuso, lobos laterais ca. $3 \times 3$ $\mathrm{mm}$, sub-ovados, ápice agudo a obtuso; ginostêmio ca. $1,1 \mathrm{~cm}$ compr.

Material examinado: Córrego Bálsamo, 27.VII.1993, fr., H.G.P. Santos et al. 157 (CEN).

Material adicional examinado: BRASIL. GOIÁS: Goiás, 5.X.1981, fl., D.C. Giacometti \& S.R.F. Fagundes 144 (CEN). Ipameri, 18.XII.1994, fl., M.C. Assis et al. 111 (CEN); 25.III.1995, fl., T.B. Cavalcanti et al. 1414 (CEN).

Camaridium ochroleucum está distribuído desde a Guatemala até a Bolívia e Brasil. No Brasil está presente no Acre, Amapá, Amazonas, Distrito Federal, Goiás, Maranhão, Mato Grosso, Minas Gerais, Pará, Rondônia e Roraima (Barros et al. 2013; World Checklist of Monocotyledons 2012). Espécie encontrada como epífita em matas próximas ao Córrego Bálsamo. Floresce entre outubro e março. Camaridium ochroleucum pode ser diferenciada das outras espécies de orquídeas ocorrentes na região estudada pelas folhas lineares e inflorescência lateral em fascículos, portando flores alvas.

3. Cleistes grandiflora (Aubl.) Schltr., Arch. Bot. São Paulo 1: 179. 1926.

Terrícola, 65-140 cm alt. Raízes com tuberoides. Caule não intumescido em pseudobulbo. Folhas cartáceas, paralelinérveas, espiraladas ao longo do caule, a maior ca. $14 \times 4 \mathrm{~cm}$, decrescendo em direção ao ápice do caule, tornando-se brácteas gradativamente, lâmina lanceolada a elípticolanceolada, base amplexicaule, ápice agudo. Inflorescência em racemo, terminal, 30-70 cm compr., pauciflora, ereta, laxa. Flores róseas, ressupinadas, pediceladas, ecalcaradas, sem calículo no ápice do ovário; sépala dorsal 6,5-7,5× 0,9-1,1 cm, linear-lanceolada, ápice agudo; sépalas laterais 6,5-7,5 × 0,9-1,1 cm, linear-lanceoladas, ápice agudo; pétalas púrpuras, 6,2-7,2 × 1,3-1,6 cm, oblanceoladas a elíptico-lanceoladas, ápice agudo a acuminado; labelo púrpura, alvescente na base e com vênulas vináceas no ápice, 6,5-7 ×2,4-2,7 cm, inteiro, âmbito oblongo, não adnato ao ginostêmio, crista central formada por papilas amarelas ou alvescentes; ginostêmio alvo, 3,4-3,6 cm compr. Material examinado: II.1993, fl., T.A.B. Dias et al. 410 (CEN).

Cleistes grandiflora está distribuída pelos estados de Amazonas, Goiás, Maranhão, Mato Grosso e Tocantins, ocorrendo também em países da América Central (Pansarin 2005; Barros et al. 2013). Cresce em solos de campos úmidos 


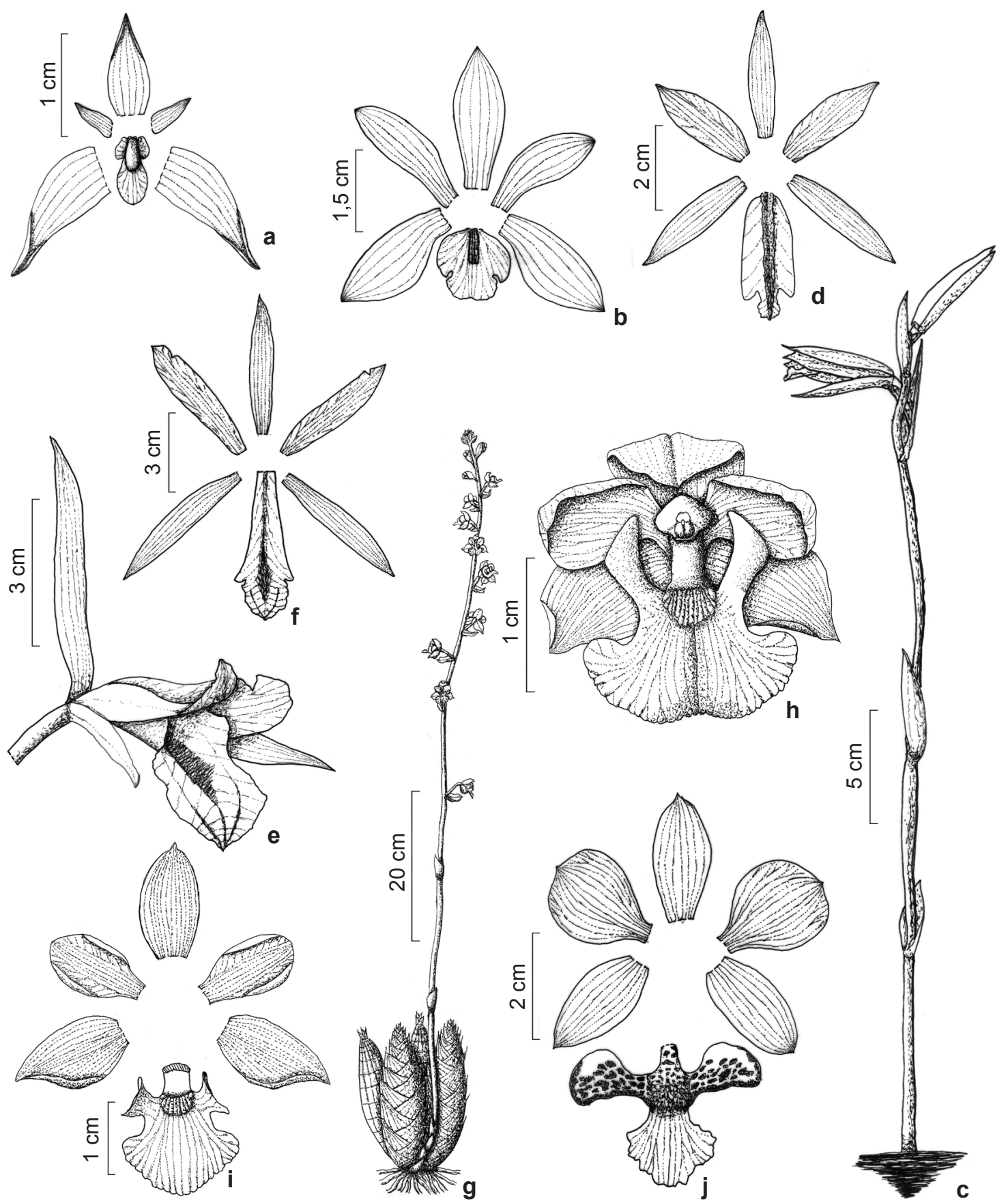

Figura 1 - a. peças florais de Bulbophyllum exaltatum; b. peças florais de Camaridium ochroleucum. c-d. Cleistes mantiqueirae - c. hábito; d. peças florais. e-f. Cleistes paranaensis - e. vista lateral da flor; f. peças florais. g-i. Cyrtopodium eugenii - g. hábito; h. flor; i. peças florais; j. peças florais de Cyrtopodium paludicolum. (a F. Barros 604; b M.C. Assis et al. 111; c-d C.F. Hall et al. 528; e-f C.F. Hall et al. 519; g-i C.F. Hall et al. 661; j CordovilSilva \& S.C.S. Xavier 537).

Figure 1 - a. floral parts of Bulbophyllum exaltatum; b. floral parts of Camaridium ochroleucum. c-d. Cleistes mantiqueirae - c. habit; d. floral parts. e-f. Cleistes paranaensis - e. flower; f. floral parts. g-i. Cyrtopodium eugenii - g. habit; h. flower; i. floral parts; j. floral parts of Cyrtopodium paludicolum. (a F. Barros 604; b M.C. Assis et al. 111; c-d C.F. Hall et al. 528; e-f C.F. Hall et al. 519; g-i C.F. Hall et al. 661; j Cordovil-Silva \& S.C.S. Xavier 537). 
próximos a áreas de cerrado sensu stricto. Floresce entre os meses de fevereiro e abril (Pansarin 2005). Cleistes grandiflora é a mais robusta dentre as espécies do gênero da região estudada, possuindo porte, folhas e flores maiores que as demais. Diferencia-se ainda de Cleistes paranaensis (Barb. Rodr.) Schltr. pelas flores róseas e labelo inteiro, com crista formada por papilas; e de C. mantiqueirae Rchb. f. \& Warm. pelo labelo púrpura e inteiro.

4. Cleistes mantiqueirae (Rchb. f. \& Warm.) Schltr., Arch Bot. São Paulo 1: 179. 1926.

Fig. 1c-d

Terrícola, ca. $60 \mathrm{~cm}$ alt. Raízes com tuberoides. Caule não intumescido em pseudobulbo. Folhas cartáceas, paralelinérveas, espiraladas ao longo do caule, a maior ca. $5,5 \times 1 \mathrm{~cm}$, decrescendo em direção ao ápice do caule, tornando-se brácteas gradativamente, lâmina lanceolada, base amplexicaule, ápice agudo. Inflorescência em racemo, terminal, ca. $30 \mathrm{~cm}$ compr., pauciflora, ereta, laxa. Flores róseo-pálidas, ressupinadas, pediceladas, ecalcaradas, sem calículo no ápice do ovário; sépala dorsal ca. $3 \times 0,5 \mathrm{~cm}$, lanceolada, ápice agudo; sépalas laterais ca. $3 \times 0,5 \mathrm{~cm}$, lanceoladas, ápice agudo; pétalas ca. 2,7 $\times 0,9 \mathrm{~cm}$, lanceoladas, ápice agudo; labelo róseo, ca. 2,8 $\times$ $0,6 \mathrm{~cm}$, trilobado, âmbito oblanceolado, não adnato ao ginostêmio, crista central formada por papilas amarelas; lobo mediano ca. $6 \times 6 \mathrm{~mm}$, orbicular, ápice agudo; ginostêmio alvo, ca. 1,8 cm compr. Material examinado: PESCAN, 27.II.2008, fl., C.F. Hall et al. 528 (UFG).

Cleistes mantiqueirae está distribuída pelos estados de Goiás, Minas Gerais, Paraná, Rio de Janeiro e São Paulo (Pansarin 2005). Espécie coletada em campos úmidos próximos a formações rupestres no PESCAN. Floresce no mês de fevereiro. Cleistes mantiqueirae é a menos robusta dentre as espécies do gênero da região estudada, possuindo porte, folhas e flores menores que as demais. Diferencia-se ainda de C. paranaensis pelas flores róseas e labelo com crista formada por papilas; e de C. grandiflora pelo labelo róseo e trilobado.

5. Cleistes paranaensis (Barb. Rodr.) Schltr., Arch. Bot. São Paulo 1: 180. 1926.

Fig. 1e-f

Terrícola, ca. $80 \mathrm{~cm}$ alt. Raízes com tuberoides. Caule não intumescido em pseudobulbo. Folhas verdes, cartáceas, paralelinérveas, espiraladas ao longo do caule, a maior ca. $8 \times 1,7 \mathrm{~cm}$, decrescendo em direção ao ápice do caule, tornando-se brácteas gradativamente, lâmina lanceolada, base amplexicaule, ápice agudo. Inflorescência em racemo, terminal, ca. $40 \mathrm{~cm}$ compr., pauciflora, ereta, laxa. Flores lilases, ressupinadas, pediceladas, ecalcaradas, sem calículo no ápice do ovário; sépala dorsal ca. 5,3 $\times 0,6 \mathrm{~cm}$, lanceolada, ápice agudo; sépalas laterais ca. $5,3 \times 0,8 \mathrm{~cm}$, lanceoladas, ápice agudo; pétalas ca. $5,2 \times 1,1 \mathrm{~cm}$, lanceoladas, ápice agudo; labelo púrpura, mais escuro em direção ao ápice, ca. $4,8 \times 2 \mathrm{~cm}$, trilobado, âmbito oblanceolado, não adnato ao ginostêmio, crista central formada por fímbrias alvescentes, lobo mediano ca. 1,1 × 1,4 $\mathrm{cm}$, suborbicular, ápice agudo; ginostêmio alvo, ca. $1,4 \mathrm{~cm}$ compr.

Material examinado: PESCAN, 27.II.2008, fl., C.F. Hall et al. 519 (UFG).

Cleistes paranaensis está distribuída pela Bahia, Distrito Federal, Goiás, Minas Gerais, Paraná, Rio de Janeiro e São Paulo (Barros et al. 2013). Espécie coletada em áreas de transição de cerrado sensu stricto para campo úmido no PESCAN. Floresce no mês de fevereiro. Cleistes paranaensis é uma das poucas espécies do gênero que ocorre com mais frequência em locais secos (Pansarin 2005). Diferencia-se das outras espécies do gênero ocorrentes na região estudada pelas flores lilases com labelo púrpura, trilobado, possuindo crista com fímbrias ao invés de papilas.

6. Cyrtopodium eugenii Rchb. f. \& Warm., Otia Bot. Hamb. 2(2): 89. $1881 . \quad$ Fig. 1g-i

Terrícola ou rupícola, ca. $1 \mathrm{~m}$ alt. Cauloma intumescido em pseudobulbo; pseudobulbos ca. $20 \mathrm{~cm}$ compr., fusiformes, multifoliados. Folhas ausentes na floração, herbáceas, plicadas, com várias nervuras longitudinais proeminentes, dísticas. Inflorescência em racemo ou panícula, lateral, ca. $1 \mathrm{~m}$ compr., multiflora. Flores ressupinadas, pediceladas, ecalcaradas; sépalas amarelo-pálidas com máculas castanhas, dorsal ca. $1,7 \times 1 \mathrm{~cm}$, elíptica, ápice agudo; laterais ca. 1,7 × 1 $\mathrm{cm}$, elípticas, ápice agudo; pétalas amarelo-pálidas com máculas castanhas, ca. $1,2 \times 1 \mathrm{~cm}$, orbiculares, ápice arredondado; labelo amarelo, ca. 1,8 × 1,6 cm, trilobado, com calos na região central, lobo mediano ca. $0,9 \times 1,5 \mathrm{~cm}$, deltoide, lobos laterais castanhos, ca. $6 \times$ $5 \mathrm{~mm}$, obovados; ginostêmio verde, ca. $7 \mathrm{~mm}$ compr. Material examinado: PESCAN, 16.VIII.2008, fl., C.F. Hall et al. 661 (UFG).

Cyrtopodium eugenii está distribuído pela Bahia, Distrito Federal, Goiás, Minas Gerais e Mato 
Grosso, ocorrendo também na Bolívia (RomeroGonzález et al. 2008). Espécie coletada nos campos rupestres do PESCAN e vista em flor entre os meses de abril e agosto. Cyrtopodium eugenii é uma das espécies do gênero mais afetadas pelos efeitos das queimadas, pois apesar de sua parte vegetativa ser resistente ao fogo, floresce na época da seca, tendo sua inflorescência destruída pelas queimadas (Menezes 2000), fato também observado no PESCAN durante o presente estudo. Diferencia-se de Cyrtopodium paludicolum Hoehne pelo padrão de coloração da flor que possui o labelo amarelo-vivo com lobos laterais castanhos e os outros verticilos amarelo-pálidos com máculas castanhas. A flor de C. eugenii também é, de maneira geral, menor que a de $C$. paludicolum apresentando, por exemplo, labelo ca. 1,8 × 1,6 cm.

7. Cyrtopodium paludicolum Hoehne, Relat. Commiss. Linhas Telegr. Estratég. Matto Grosso Amazonas 4: 24. 1912.

Fig. $1 \mathrm{j}$

Terrícola, ca. 1,45 m alt. Cauloma intumescido em pseudobulbo; pseudobulbos 15,5-18,5 cm compr., fusiformes, multifoliados. Folhas herbáceas, plicadas, com várias nervuras longitudinais proeminentes, dísticas, ca. $50 \times$ 1,7-2 cm, lineares, ápice agudo. Inflorescência em racemo, lateral, ca. 1,45 m compr., multiflora. Flores predominantemente amarelas, ressupinadas, pediceladas, ecalcaradas; sépala dorsal ca. 2,4 $\times 1$ $\mathrm{cm}$, elíptica, ápice acuminado; sépalas laterais ca. 2 $\times 1 \mathrm{~cm}$, elípticas, ápice acuminado; pétalas ca. $2,1 \times$ $1,7 \mathrm{~cm}$, orbiculares, ápice acuminado; labelo amarelo com máculas vermelhas na região do calo e lobos laterais, ca. $2,2 \times 3,5 \mathrm{~cm}$, trilobado, com calos na região central; lobo mediano ca. 1,1 × 1,7 cm, deltoide, ápice arredondado, lobos laterais, ca. 1,5 $\times 1 \mathrm{~cm}$, obovados; ginostêmio amarelo-esverdeado, $8-9$ mm compr.

Material examinado: desvio da estrada Caldas NovasAHE Corumbá, 16.I.1997, f1., S.P. Cordovil-Silva \& S.C.S. Xavier 537 (CEN).

Cyrtopodium paludicolum está distribuído pelo Distrito Federal, Goiás, Minas Gerais, Mato Grosso, Mato Grosso do Sul, Paraná e São Paulo, ocorrendo também na Bolívia (Romero-González et al. 2008). Espécie coletada em áreas de campo úmido. Floresce de dezembro a abril (Menezes 2000). Diferencia-se de $C$. eugenii pelo padrão de coloração da flor que é inteiramente amarelo-vivo, com labelo apresentando máculas vermelhas na região do calo e nos lobos laterais. A flor de Cyrtopodium paludicolum também é, de maneira geral, maior que a de $C$. eugenii, apresentando, por exemplo, labelo ca. 2,2 × 3,5 cm.
8. Encyclia argentinensis (Speg.) Hoehne, Arq. Bot. Est. São Paulo 2(6): 150. $1952 . \quad$ Fig. 2a-b

Epífita, ca. 1,3 m alt. Cauloma intumescido em pseudobulbo; pseudobulbos 9-11 cm compr., cônico-alongados, uni ou bifoliados. Folhas coriáceas, ca. $43 \times 1,6 \mathrm{~cm}$, lineares, ápice agudo. Inflorescência em panícula, terminal, ca. 1,3 m compr., multiflora, ereta, laxa. Flores castanho-esverdeadas, ressupinadas, pediceladas, ecalcaradas; sépala dorsal castanho-esverdeada, $1,8-2,4 \times 0,4-0,6 \mathrm{~cm}$, estreito-elíptica, ápice agudo; sépalas laterais castanho-esverdeadas, $1,9-2,4 \times 0,4-0,6 \mathrm{~cm}$, estreito-elípticas, ápice agudo; pétalas castanho-esverdeadas, 1,8-2,1 $\times$ 0,4-0,6 cm, oblanceoladas, ápice agudo; labelo alvo com vênulas róseas, ca. $1,8 \times 2,1 \mathrm{~cm}$, trilobado, envolvendo o ginostêmio em sua base, lobo mediano $1-1,2 \times 0,7-0,8 \mathrm{~cm}$, suborbicular, ápice arredondado, lobos laterais $0,9-1,1 \times 0,3-0,5 \mathrm{~cm}$, subtrapezoidais; ginostêmio alvo a creme, ca. $1 \mathrm{~cm}$ compr.

Material examinado: 13.X.1990, fl., L.C. Menezes 7(UB). Material adicional examinado: BRASIL. GOIÁS: Morrinhos, 28.XI.1970, fl., J.A. Rizzo 5772 \& A. Barbosa 5020 (UFG).

Encyclia argentinensis está distribuída por Goiás, Espírito Santo, Minas Gerais, Mato Grosso, Mato Grosso do Sul, Paraná, Rondônia, São Paulo e Tocantins, ocorrendo também na Argentina (Barros et al. 2013; World Checklist of Monocotyledons 2012). Floresce entre agosto e novembro (Meneguzzo $\mathrm{et}$ al. 2012). Encyclia argentinensis pode ser diferenciada das outras espécies de orquídeas ocorrentes na região estudada por suas folhas coriáceas, longas (ca. 43 $\mathrm{cm}$ compr.), e inflorescência terminal, muito longa (ca. 1,3 m compr.).

9. Epidendrum amblostomoides Hoehne, Arq. Bot. Estado São Paulo, n.s., f.m., 1(1): 18. 1938.

Fig. 2c

Epífita, ereta, 15,5-22,5 cm alt. Caule não ramificado. Cauloma intumescido em pseudobulbo; pseudobulbos 8-15 cm compr., fusiformes, multifoliados. Folhas cartáceas, dísticas, 8,2-16 $\times$ $0,3-0,5 \mathrm{~cm}$, lineares, base em bainha amplexicaule, ápice obtuso. Inflorescência em racemo, terminal, ca. 7,5 cm compr., multiflora, ereta, laxa. Flores alvo-esverdeadas, ressupinadas, pediceladas, ecalcaradas; pedicelo e ovário não encobertos pelas brácteas; sépala dorsal ca. $5 \times 1 \mathrm{~mm}$, oblanceolada, ápice agudo; sépalas laterais $4-5 \times 1-1,5 \mathrm{~mm}$, oblongas a elípticas, falcadas, ápice agudo; pétalas ca. 4-5 ×0,5 mm, linear-filiformes, ápice dilatado, 


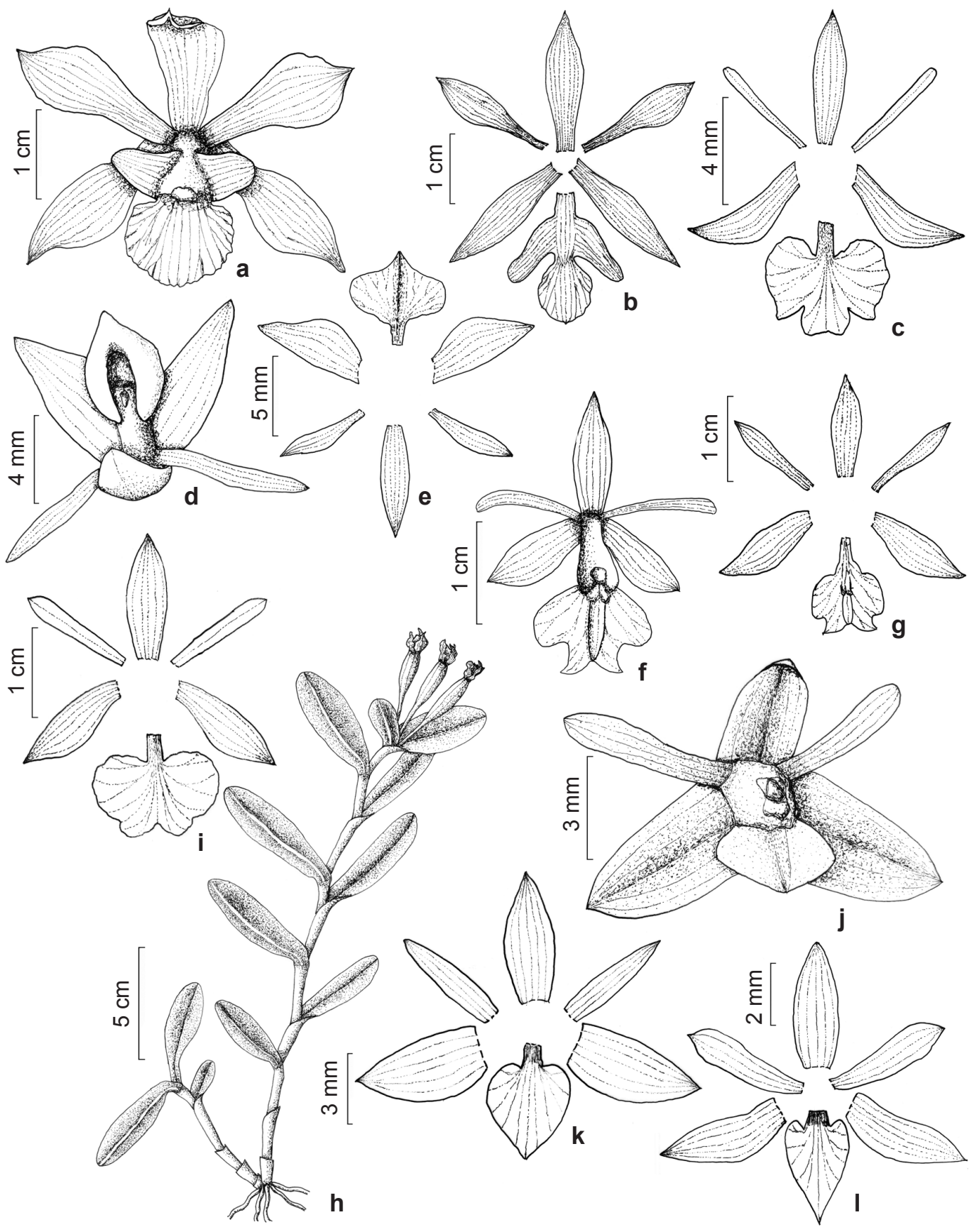

Figura 2 - a-b. Encyclia argentinensis - a. vista frontal da flor; b. peças florais. c. peças florais de Epidendrum amblostomoides. d-e. Epidendrum dendrobioides - d. flor; e. peças florais. f-g Epidendrum densiflorum - f. vista frontal da flor; g. peças florais. h-i. Epidendrum pseudodifforme - h. hábito; i. peças florais. j-k. Epidendrum rigidum - j. flor; k. peças florais. 1. peças florais de Epidendrum strobiliferum. (a material vivo; b L.C. Menezes 7; c T.B. Cavalcanti et al. 1969; d material vivo; e M.C. Assis et al. 156; f material vivo; g G.P. Silva et al. 1924; h T.A.B. Dias et al. 427; i C. Spannagel 11; j material vivo; k L. Bianchetti et al. 1237; 1 T.A.B. Dias et al. 364).

Figure 2 - a-b. Encyclia argentinensis - a. flower front view; b. floral parts. c. floral parts of Epidendrum amblostomoides. d-e. Epidendrum dendrobioides - d. flower; e. flower parts. f-g Epidendrum densiflorum - f. flower front view; g. floral parts. h-i. Epidendrum pseudodifforme - h. habit; i. floral parts. j-k. Epidendrum rigidum - j. flower; $\mathrm{k}$. floral parts; 1. floral parts of Epidendrum strobiliferum. (a live material; b L.C. Menezes 7; c T.B. Cavalcanti et al. 1969; d live material; e M.C. Assis et al. 156; f live material; g G.P. Silva et al. 1924; h T.A.B. Dias et al. 427; i C. Spannagel 11; j live material; k L. Bianchetti et al. 1237; 1 T.A.B. Dias et al. 364). 
arredondado; labelo ca. $4 \times 2-3 \mathrm{~mm}$, trilobado, unguículo adnato às margens do ginostêmio, lobo mediano ca. $1 \times 1 \mathrm{~mm}$, ovado, lobos laterais ca. $1 \times$ $1 \mathrm{~mm}$, suborbiculares; ginostêmio 2,5-3 mm compr. Material examinado: margem do Rio Corumbá, 29.IV.1993, fl., R.F. Vieira et al. 1454 (CEN); 26.IV.1994, fl., H. G.P. Santos et al. 248 (CEN); 11.VI.1996, fl., T.B. Cavalcanti et al. 1969 (CEN).

Epidendrum amblostomoides está distribuído pelo Distrito Federal, Goiás, Maranhão, Pará e Rondônia (Barros et al. 2013). Espécie coletada em matas ciliares nas margens do Rio Corumbá. Floresce entre abril e junho. Epidendrum amblostomoides pode ser diferenciada das outras espécies do gênero ocorrentes na região estudada pelo caule intumescido em pseudobulbo.

10. Epidendrum dendrobioides Thunb., Pl. Bras. 2: 17.1818 .

Fig. 2d-e

Terrícola, ereta, 46-57,5 cm alt. Caule ramificado. Cauloma não intumescido em pseudobulbo, 40-48 cm compr. Folhas coriáceas, dísticas ao longo do caule, 2,4-7 × 0,6-1 cm, lanceoladas, base em bainha amplexicaule, ápice agudo. Inflorescência em panícula (raramente racemo), terminal, 6-9,5 cm compr., multiflora, ereta, laxa. Flores amarelo-esverdeadas, não ressupinadas, pediceladas, ecalcaradas; pedicelo e ovário não encobertos pelas brácteas; sépala dorsal ca. $7 \times 2 \mathrm{~mm}$, oblongo-elíptica, ápice agudo; sépalas laterais ca. 8-8,5 × $3 \mathrm{~mm}$, elípticas, assimétricas, ápice agudo; pétalas ca. 6-7 × $1 \mathrm{~mm}$, estreito-elípticas, ápice agudo; labelo ca. $8 \times 6,5$ $\mathrm{mm}$, inteiro, largo-ovado, conduplicado, unguículo adnato às margens do ginostêmio, ápice agudo; ginostêmio ca. $3 \mathrm{~mm}$ compr.

Material examinado: estrada de acesso a usina, 19.XII.1994, fl., M.C. Assis et al. 156 (CEN).

Epidendrum dendrobioides está distribuído no Brasil pelos estados da Bahia, Distrito Federal, Goiás, Mato Grosso, Mato Grosso do Sul, Minas Gerais, Rio de Janeiro, São Paulo e Tocantins, ocorrendo também na Venezuela (Stancik et al. 2009; Barros et al. 2013). Espécie coletada em campos úmidos. Floresce entre setembro e maio (Stancik et al. 2009). Epidendrum dendrobioides pode ser diferenciada das outras espécies do gênero na região estudada pelo labelo conduplicado.

11. Epidendrum densiflorum Hook., Curtis's Bot. Mag. 67: t. 3791. 1840.

Fig. 2f-g

Terrícola, ereta, ca. $93 \mathrm{~cm}$ alt. Caule não ramificado. Cauloma não intumescido em pseudobulbo, ca. $75 \mathrm{~cm}$ compr. Folhas coriáceas, dísticas ao longo do caule, ca. 15,3 × 2,6 cm, estreito-elípticas, base em bainha amplexicaule, ápice agudo. Inflorescência em panícula, terminal, ca. $18 \mathrm{~cm}$ compr., multiflora, arqueada, congesta. Flores alvo-esverdeadas, ressupinadas, pediceladas, ecalcaradas; pedicelo e ovário não encobertos pelas brácteas; sépala dorsal ca. 1,1-1,2 ×0,3 $\mathrm{cm}$, oblanceolada, ápice agudo; sépalas laterais ca. 1,1-1,2 × 0,3 cm, oblanceoladas, levemente assimétricas, ápice agudo; pétalas ca. 1-1,1 × 0,1 $\mathrm{cm}$, estreito-oblanceoladas, ápice agudo; labelo alvo, ca. $1 \times 0,8 \mathrm{~cm}$, trilobado, plano, unguículo adnato às margens do ginostêmio, lobo mediano bífido, segmentos ca. $2 \times 2 \mathrm{~mm}$, triangulares, lobos laterais ca. $3 \times 6 \mathrm{~mm}$, suborbiculares; ginostêmio 8-9 $\mathrm{mm}$ compr.

Material examinado: margem do Rio Corumbá, 22.IX.1993, fl., G.P. Silva et al. 1924 (CEN).

Epidendrum densiflorum está distribuído no Brasil pelos estados de Amazonas, Bahia, Distrito Federal, Espírito Santo, Goiás, Mato Grosso, Mato Grosso do Sul, Minas Gerais, Pará, Paraná, Rio de Janeiro, Rio Grande do Sul, Roraima, Santa Catarina, São Paulo e Tocantins, ocorrendo também na Colômbia, Costa Rica, Equador, Guiana Francesa e Venezuela (Stancik et al. 2009; Barros et al. 2013). Espécie encontrada como terrícola no interior de matas próximas ao Rio Corumbá, hábito que se diferencia do que normalmente ocorre com a espécie, que é tipicamente epífita ou rupícola. Floresce praticamente durante todo o ano (Stancik et al. 2009). Epidendrum densiflorum é a maior e mais robusta espécie de Epidendrum da região estudada. Pode ser diferenciada das outras espécies do gênero ocorrentes na região pelo labelo trilobado com o lobo mediano bífido.

12. Epidendrum pseudodifforme Hoehne \& Schltr., Repert. Spec. Nov. Regni Veg. Beih. 35: 71. 1925.

Fig. 2h-i

Epífita, ereta, 19,8-26,2 cm alt. Caule não ramificado. Cauloma não intumescido em pseudobulbo, 16,8-22,2 cm compr. Folhas coriáceas, dísticas ao longo do caule, 2,8-6,5 $\times$ 1,3-2 cm, elípticas, base em bainha amplexicaule, ápice arredondado a emarginado. Inflorescência em racemo, subumbelada, terminal, 3-4 cm compr., multiflora, ereta, congesta. Flores verdes, ressupinadas, pediceladas, ecalcaradas; pedicelo e ovário não encobertos pelas brácteas; sépala dorsal 11,5-17 × 4-4,5 mm, elíptica, ápice agudo; 
sépalas laterais $12-16 \times 4-5,5 \mathrm{~mm}$, elípticas, subfalcadas, ápice agudo; pétalas 11-16 × 1,5-2 mm, oblanceoladas, ápice agudo a obtuso; labelo 10-19× 13-20 mm, trilobado a inteiro, unguículo adnato às margens do ginostêmio, lobo mediano $1-2 \times 3-4,5$ $\mathrm{mm}$, ápice emarginado, lobos laterais 4-5 × 8-11 $\mathrm{mm}$, suborbiculares; ginostêmio 6-9 mm compr. Material examinado: próximo ao Rio Corumbá, 12.II.1993, fr., T.A.B. Dias et al. 427 (CEN).

Material adicional examinado: BRASIL. RIO DE JANEIRO: Petrópolis, fl. C. Spannagel 11 (SP). SÃO PAULO: São Paulo, Butantan, 18.I.1918, fl., A. Gehrt (SP1332); 16.I.1922, fl., F.C. Hoehne (SP29313)

Epidendrum pseudodifforme está distribuído pelas Américas Central e do Sul. No Brasil ocorre em Goiás, Minas Gerais, Paraná, Rio de Janeiro, Rio Grande do Sul, Santa Catarina e São Paulo (Stancik et al. 2009; Barros et al. 2013). Espécie coletada em matas de galeria próximas ao Rio Corumbá. Floresce em janeiro (Stancik et al. 2009). Epidendrum pseudodifforme pode ser diferenciada das outras espécies do gênero ocorrentes na região estudada pela inflorescência em racemo muito curto, subumbelada, 3-4 cm compr.

13. Epidendrum rigidum Jacq., Enum. Syst. P1. p. 29. 1760. Fig. $2 \mathrm{j}-\mathrm{k}$

Epífita, ereta, 12-25,5 cm alt. Caule não ramificado. Cauloma não intumescido em pseudobulbo, 6-12,5 cm compr. Folhas coriáceas, dísticas ao longo do caule, 3,5-6,4 × 1,2-1,9 $\mathrm{cm}$, elípticas a estreito-elípticas, base em bainha amplexicaule, ápice arredondado a emarginado. Inflorescência em racemo, terminal, 6-13 cm compr., pauciflora a multiflora, ereta, laxa. Flores verdes, não ressupinadas, pediceladas, ecalcaradas; pedicelo e ovário encobertos por brácteas florais cimbiformes de base imbricante; sépala dorsal ca. 5,5 × 2,3 mm, oblongo-elíptica, ápice obtuso; sépalas laterais ca. 5,5 × 2,5 mm, oblongo-ovadas, sub-falcadas, ápice obtuso; pétalas ca. $5 \times 1 \mathrm{~mm}$, estreito-oblongas, ápice agudo; labelo ca. $5 \times 3 \mathrm{~mm}$, inteiro, ovado, ápice obtuso, unguículo adnato às margens do ginostêmio; ginostêmio ca. 3 mm compr. Material examinado: Fazenda Geraldinho, 22.III.1993, fr., T.A. Dias et al. 443 (CEN); Próximo ao Rio Corumbá, 10.II.1993, fl., T.A. Dias et al. 365 (CEN); 26.IV.1994, fr., H.G.P. Santos et al. 249 (CEN); 11.VI.1996, fr., T.B. Cavalcanti et al. 1966 (CEN).

Material adicional examinado: BRASIL. GOIÁS: Pirenópolis, Santuário Ecológico do Vaga Fogo, 5.III.1992, fl., L. Bianchetti et al. 1237 (CEN)

Epidendrum rigidum está distribuído desde a América Central até a Bolívia e o Brasil, onde ocorre nos estados de Alagoas, Amazonas, Bahia, Ceará, Espírito Santo, Goiás, Maranhão, Mato Grosso do Sul, Minas Gerais, Pará, Paraíba, Paraná, Pernambuco, Rio de Janeiro, Rio Grande do Sul, Rondônia, Roraima, Santa Catarina, São Paulo e Tocantins (Stancik et al. 2009; Barros et al. 2013). Espécie coletada em matas de galeria próximas ao Rio Corumbá. Floresce entre novembro e julho (Stancik et al. 2009). Epidendrum rigidum pode ser diferenciada das outras espécies do gênero ocorrentes na região estudada pela inflorescência de $6-13 \mathrm{~cm}$ compr., portando flores verdes com pedicelo e ovário encobertos por brácteas florais cimbiformes de base imbricante.

14. Epidendrum strobiliferum Rchb.f., Ned. Kruidk. Arch. 4: 333. 1859.

Fig. 21

Epífita, pendente, $11,5-58 \mathrm{~cm}$ alt. Caule ramificado. Cauloma não intumescido em pseudobulbo, 10-56 cm compr. Folhas coriáceas, dísticas ao longo do caule, 1,3-3,1 × 0,5-0,6 cm, lanceoladas a estreito-elípticas, base em bainha amplexicaule, ápice arredondado. Inflorescência em racemo, terminal, 1,5-2 cm compr., pauciflora, ereta, congesta. Flores alvo-esverdeadas, ressupinadas, pediceladas, ecalcaradas; pedicelo, ovário e parte da flor encobertos por brácteas florais cimbiformes de base imbricante; sépala dorsal ca. 4 $\times 1 \mathrm{~mm}$, lanceolada, ápice obtuso; sépalas laterais ca. $4 \times 1 \mathrm{~mm}$, ovado-lanceoladas, assimétricas, ápice agudo; pétalas ca. 3,5-4 × $1 \mathrm{~mm}$, estreitooblongas a oblanceoladas, ápice obtuso; labelo ca. $4 \times 2 \mathrm{~mm}$, inteiro, ovado a cordiforme, unguículo adnato às margens do ginostêmio, ápice agudo; ginostêmio ca. $2 \mathrm{~mm}$ compr.

Material examinado: próximo ao Rio Corumbá, 10.II.1993, fl., T.A.B. Dias et al. 364 (CEN); 11.VI.1996, fr., T.B. Cavalcanti et al. 1968 (CEN).

Epidendrum strobiliferum está distribuído pelos estados do Acre, Alagoas, Amapá, Amazonas, Goiás, Maranhão, Mato Grosso, Minas Gerais, Pará, Paraná, Pernambuco, Roraima e São Paulo, ocorrendo também na Guiana Francesa (Stancik et al. 2009; Barros et al. 2013). Espécie coletada em matas de galeria próximas ao Rio Corumbá. Floresce em janeiro e fevereiro (Stancik et al. 2009). Epidendrum strobiliferum pode ser diferenciada das demais espécies do gênero ocorrentes na região estudada pelo hábito pendente com caule ramificado e inflorescência curta de 1,5-2 cm compr., portando flores alvo-esverdeadas com pedicelo, ovário e parte da flor encobertos por brácteas florais cimbiformes de base imbricante. 
15. Epistephium sclerophyllum Lindl., Gen. Sp. Orchid. Pl. p. 433. 1840. Fig. 3a-b

Terrícola, ca. 73,5 cm alt. Raízes destituídas de tuberoides. Caule não intumescido em pseudobulbo. Folhas coriáceas, espiraladas ao longo do caule, sésseis, nervação reticulada, $4-11,4 \times 2,9-6,7 \mathrm{~cm}$, arredondadas a ovallanceoladas, base arredondada a cordada, ápice agudo a emarginado. Inflorescência em racemo, terminal, 30,9-32,3 cm compr., pauciflora, ereta, laxa. Flores lilases, ressupinadas, pediceladas, ecalcaradas, com calículo no ápice do ovário; sépala dorsal 3,9-4,7 ×0,8-1,1 cm, oblanceolada, ápice agudo; sépalas laterais 4,6-5,5 × 0,9-1,3 $\mathrm{cm}$, oblanceoladas, ápice agudo; pétalas 4,5-5,5× $0,8-1,3 \mathrm{~cm}$, oblanceoladas, ápice agudo a obtuso; labelo lilás com centro alvo e estrias lilases, 4,5-6,4 $\times 3,3-4,2 \mathrm{~cm}$, âmbito ovado, ápice fendido, não adnato ao ginostêmio, crista central com tricomas alvos; ginostêmio alvo, ca. $3,4 \mathrm{~cm}$ compr.

Material examinado: 27.II.1974, fl., E.P. Heringer et al. 13132 (UNB); Serra de Caldas, 27.II.1974, fl., E.P. Heringer et al. 13124 (UNB).

Epistephium sclerophyllum está distribuído pelo Amazonas, Bahia, Distrito Federal, Goiás, Mato Grosso, Mato Grosso do Sul, Minas Gerais, Pará, Paraná, São Paulo e Tocantins, ocorrendo também no Paraguai, Peru e Bolívia (Pabst \& Dungs 1975; Barros et al. 2013). Espécie coletada em áreas de cerrado sensu stricto e campo sujo. Floresce no mês de fevereiro. Epistephium sclerophyllum pode ser diferenciada das outras espécies de orquídeas ocorrentes na região estudada pelas folhas coriáceas com nervação reticulada e flores com presença de calículo no ápice do ovário.

16. Galeandra montana Barb. Rodr., Gen. Sp. Orchid. 2: 175. 1881.

Fig. 3c-e

Terrícola, ca. $50 \mathrm{~cm}$ alt. Cauloma intumescido em pseudobulbo; pseudobulbos subterrâneos a parcialmente subterrâneos, $5-5,5 \mathrm{~cm}$ compr., ovoides, multifoliados. Folhas herbáceas, plicadas, dísticas, 45-50 × 2-2,5 cm, lineares, ápice agudo. Inflorescência em racemo, terminal, ca. $30 \mathrm{~cm}$ compr., pauciflora, ereta, laxa. Flores castanhoesverdeadas, ressupinadas, pediceladas, calcaradas; calcar saquiforme, formado pela porção basal do labelo; sépala dorsal ca. $3,5 \times 0,5 \mathrm{~cm}$, lanceolada, ápice acuminado; sépalas laterais ca. $4 \times 0,8 \mathrm{~cm}$, lanceoladas, subfalcadas, ápice agudo; pétalas ca. $3 \times 0,5 \mathrm{~cm}$, lanceoladas, ápice agudo; labelo creme com ápice vinoso, ca. $4 \times 4,7 \mathrm{~cm}$, trilobado, âmbito romboide, disco carenado, lobo mediano ca. $1 \times 2$ $\mathrm{cm}$, suborbicular, ápice arredondado, lobos laterais suborbiculares; ginostêmio creme, ca. 1,3 cm compr. Material examinado: PESCAN, 27.II.2008, fl., C.F. Hall et al. 533 (UFG).

Galeandra montana está distribuída pela Bahia, Distrito Federal, Goiás, Maranhão, Mato Grosso, Minas Gerais, Pará, Rio Grande do Norte, São Paulo, Sergipe e Tocantins (Barros et al. 2013). Espécie coletada nos campos rupestres do PESCAN, ocorrendo em solo pedregoso. Espécie vista em flor na área de estudo entre os meses de janeiro e março. Galeandra montana pode ser diferenciada das outras espécies de orquídeas ocorrentes na região estudada pelos pseudobulbos subterrâneos ou parcialmente subterrâneos e flores com calcar saquiforme.

17. Habenaria glaucophylla Barb. Rodr., Gen. Sp. Orch. Nov. 1: 160. 1877. Fig. 3f

Terrícola, ca. $30 \mathrm{~cm}$ alt. Caule não intumescido em pseudobulbo. Folhas herbáceas, basais, rosuladas, $5,5-18 \times 1,9-4,8 \mathrm{~cm}$, lanceoladas a oblongo-lanceoladas, às vezes obovadas, base amplexicaule, ápice acuminado. Inflorescência em racemo, terminal, ca. $30 \mathrm{~cm}$ compr., pauciflora, ereta, laxa. Flores alvo-esverdeadas, ressupinadas, pediceladas, calcaradas; cálcar 1,2-1,8 cm compr.; sépala dorsal 4-5 × 3-4 mm, largo-ovada, ápice mucronado; sépalas laterais $5-6 \times 2-3 \mathrm{~mm}$, triangular-ovadas, ligeiramente assimétricas, ápice mucronado; pétalas bipartidas, segmento superior ca. 4,5 $\times 1 \mathrm{~mm}$, lanceolado, ligeiramente assimétrico, ápice mucronado, segmento inferior reduzido a um pequeno dente, ca. $0,5 \mathrm{~mm}$ compr.; labelo tripartido, dilatado na base, segmento mediano ca. 5-6,5 × $1 \mathrm{~mm}$, linear-filiforme, ápice agudo, segmentos laterais ca. 5-6 $61 \mathrm{~mm}$, linear-filiformes, ápice agudo; ginostêmio ca. 3 mm compr.

Material examinado: Serra de Caldas Novas, 3.III.1969, fl., J.A. Rizzo \& A. Barbosa 3766 (UFG).

Habenaria glaucophylla está distribuída pelo Distrito Federal, Goiás, Minas Gerais, Pernambuco e São Paulo (Barros et al. 2013). Espécie coletada, na Serra de Caldas Novas, em áreas de cerrado e campo rupestre, hábitat diferente do que normalmente é referido para a espécie, a qual segundo Batista et al. (2011) é típica de ambientes florestais. Floresce em março. Habenaria glaucophylla pode ser diferenciada das outras espécies do gênero ocorrentes na região 


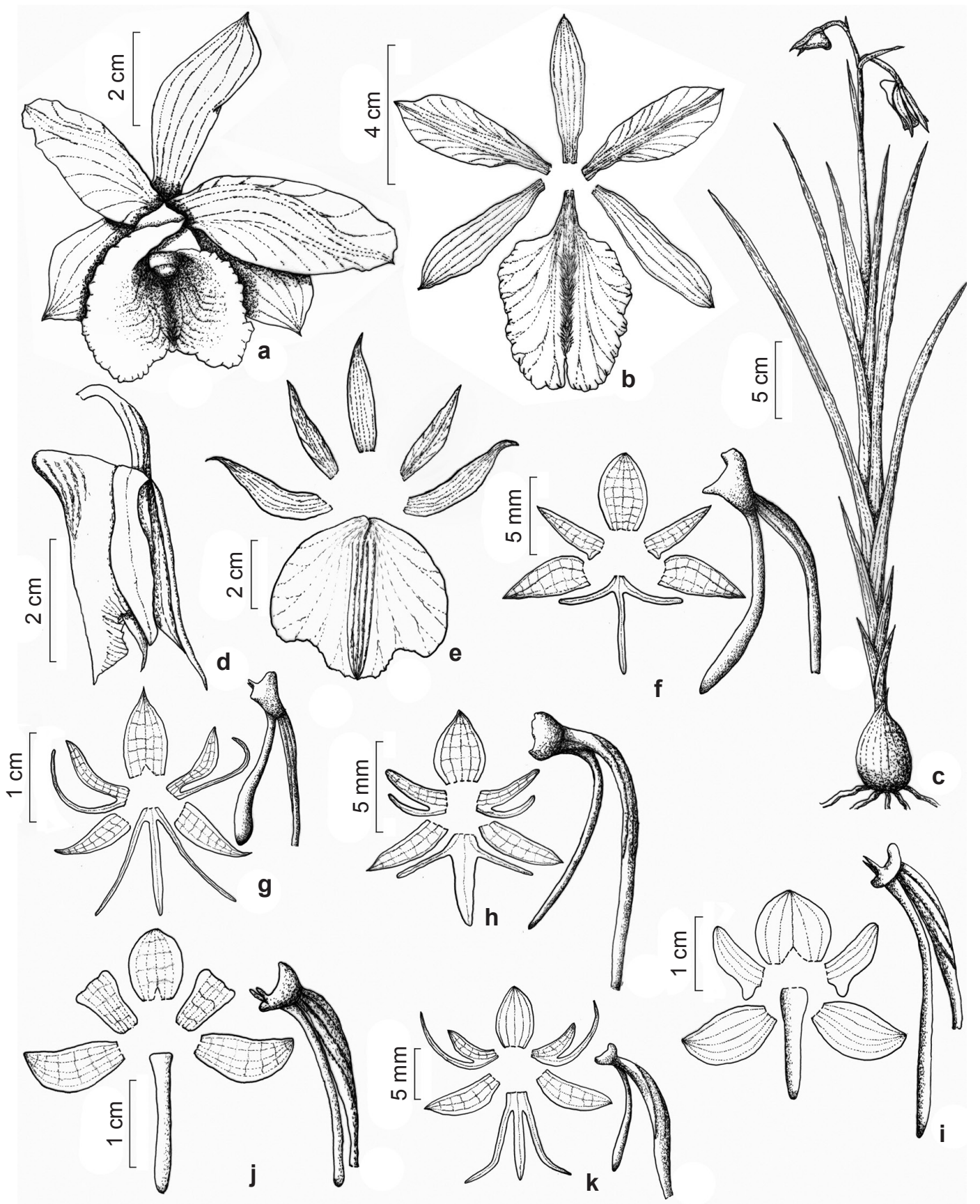

Figura 3 - a-b. Epistephium sclerophyllum - a. vista frontal da flor; b. peças florais. c-e. Galeandra montana - c. hábito; d. vista lateral da flor; e. peças florais. f. peças florais de Habenaria glaucophylla. g. peças florais de Habenaria lavrensis. h. peças florais de Habenaria leprieuri. i. peças florais de Habenaria obtusa. j. peças florais de Habenaria petalodes. k. peças florais de Habenaria secundiflora. (a material vivo; b E.P. Heringer et al. 13132; c-e C.F. Hall et al. 533; f J.A. Rizzo \& A. Barbosa 3766; g J.A. Rizzo 4796 \& A. Barbosa 4042; h C.F. Hall et al. 532; i J.A. Rizzo \& A. Barbosa 3544; j C.F. Hall et al. 526; k C.F. Hall et al. 522).

Figure 3 - a-b. Epistephium sclerophyllum - a. flower front view; b. floral parts of. c-e. Galeandra montana - c. habit; d. flower lateral view; e. floral parts. f. floral parts of Habenaria glaucophylla. g. floral parts of Habenaria lavrensis. h. floral parts of Habenaria leprieuri. i. floral parts of Habenaria obtusa. j. floral parts of Habenaria petalodes. k. floral parts of Habenaria secundiflora. (a live material; b E.P. Heringer et al. 13132; c-e C.F. Hall et al. 533; f J.A. Rizzo \& A. Barbosa 3766; g J.A. Rizzo 4796 \& A. Barbosa 4042; h C.F. Hall et al. 532; i J.A. Rizzo \& A. Barbosa 3544; j C.F. Hall et al. 526; k C.F. Hall et al. 522). 
estudada pelas folhas basais, rosuladas, o que é uma característica bastante rara entre as espécies brasileiras do gênero.

18. Habenaria lavrensis Hoehne, Arch. Bot. Est. S. Paulo 1(4): 575. 1927.

Fig. $3 g$

Terrícola, 23-38 cm alt. Caule não intumescido em pseudobulbo. Folhas herbáceas, espiraladas ao longo do caule, a maior ca. $8 \times 0,1 \mathrm{~cm}$, decrescendo em direção ao ápice do caule, tornando-se brácteas gradativamente, lâminas linear-filiformes, base amplexicaule, ápice agudo. Inflorescência em racemo, terminal, ca. $6 \mathrm{~cm}$ compr., pauciflora, ereta, sub-laxa. Flores alvo-esverdeadas, ressupinadas, pediceladas, calcaradas; cálcar 1,2-1,5 cm compr.; sépala dorsal ca. $10 \times 5 \mathrm{~mm}$, ovada, ápice longamente acuminado a caudado; sépalas laterais ca. $9 \times 3 \mathrm{~mm}$, ovado-triangulares, ápice longamente acuminado a caudado; pétalas bipartidas, segmento superior ca. 8-9 × $1 \mathrm{~mm}$, falciforme, ápice agudo, segmento inferior 1,1-1,5 cm compr., filiforme, ápice agudo; labelo tripartido, dilatado na base, segmento mediano ca. $1,1 \times 0,1 \mathrm{~cm}$, linear, ápice agudo, segmentos laterais ca. 1,1 cm compr., filiformes; ginostêmio ca. $3 \mathrm{~mm}$ compr.

Material examinado: alto da Serra de Caldas Novas, 28.II.1970, fl., J.A. Rizzo 4796 \& A. Barbosa 4042 (UFG).

Habenaria lavrensis está distribuída pelo Distrito Federal, Goiás e Minas Gerais (Barros et al. 2013). Espécie coletada em áreas de cerrado e campo rupestre da Serra de Caldas Novas. Floresce em fevereiro. Habenaria lavrensis pode ser diferenciada das outras espécies do gênero ocorrentes na região estudada pela sépala dorsal com ápice longamente acuminado a caudado.

19. Habenaria leprieuri Rchb. f., Linnaea 19: 376. 1846.

Fig. $3 \mathrm{~h}$

Terrícola, $28-45 \mathrm{~cm}$ alt. Caule não intumescido em pseudobulbo. Folhas herbáceas, espiraladas ao longo do caule, a maior ca. $8-12,5$ $\times 0,1 \mathrm{~cm}$, decrescendo em direção ao ápice do caule, tornando-se brácteas gradativamente, lâminas aciculares, base amplexicaule, ápice agudo. Inflorescência em racemo, terminal, 5,5-7 cm compr., pauciflora, ereta, sub-laxa. Flores verdes, ressupinadas, pediceladas, calcaradas; cálcar ca. $9 \mathrm{~mm}$ compr.; sépala dorsal ca. $4 \times 3 \mathrm{~mm}$, ovada, ápice agudo; sépalas laterais ca. $4 \times 2 \mathrm{~mm}$, oblongas, falcadas, ápice agudo; pétalas bipartidas, segmento superior ca. $3 \times 1 \mathrm{~mm}$, linear, ápice agudo, segmento inferior ca. $5 \times 1 \mathrm{~mm}$, linear, ápice agudo; labelo ca. $5 \mathrm{~mm}$ compr., tripartido, dilatado na base, segmento mediano ca. $5 \times 1 \mathrm{~mm}$, linear, ápice agudo, segmentos laterais ca. $5 \times 1 \mathrm{~mm}$, lineares, ápice agudo; ginostêmio ca. $2 \mathrm{~mm}$ compr. Material examinado: PESCAN, 27.II.2008, fl., C.F. Hall et al. 532 (UFG).

Habenaria leprieuri está distribuída no Brasil pelos estados do Amapá, Distrito Federal, Goiás, Minas Gerais, Mato Grosso, Pará, Roraima, São Paulo e Tocantins, ocorrendo também na Guiana, Guiana Francesa, Suriname, Trinidad-Tobago e Venezuela (Batista et al. 2008). Espécie coletada em campos úmidos do PESCAN e vista em flor, na área de estudo, entre janeiro e março. Dentre as espécies ocorrentes na região estudada, $H$. leprieuri possui grande semelhança com $H$. secundiflora tanto na morfologia dos órgãos vegetativos quanto na das peças florais e no tipo de fisionomia em que ocorrem, diferenciando-se principalmente pelo porte, pois é um pouco menor, com folhas mais estreitas e flores um pouco mais delicadas e menores.

20. Habenaria obtusa Lindl., Gen. Sp. Orchid. Pl. p. 315.1835.

Fig. 3i

Terrícola, ca. $56 \mathrm{~cm}$ alt. Caule não intumescido em pseudobulbo. Folhas herbáceas, espiraladas ao longo do caule, a maior $9,5-11 \times 2,2-8 \mathrm{~cm}$, decrescendo em direção ao ápice do caule, tornando-se brácteas gradativamente, lâminas lanceoladas, base amplexicaule, ápice agudo. Inflorescência em racemo, terminal, 15-17 cm compr., multiflora, ereta, sub-laxa. Flores verdealvescentes, ressupinadas, pediceladas, calcaradas; cálcar ca. 4,5 cm compr.; sépala dorsal ca. $8 \times 7$ $\mathrm{mm}$, suborbicular, ápice obtuso; sépalas laterais ca. $10 \times 6 \mathrm{~mm}$, obovadas, ligeiramente assimétricas, ápice arredondado; pétalas bipartidas, segmento superior ca. $8 \times 3 \mathrm{~mm}$, triangular-lanceolado, ligeiramente assimétrico, segmento inferior reduzido a um pequeno dente, ca. $1 \mathrm{~mm}$ compr.; labelo ca. 1,5 ×0,2 cm, inteiro, linear, revoluto, dilatado na base; ginostêmio ca. $5 \mathrm{~mm}$ compr.

Material examinado: Cia Termas do Rio Quente, 7.I.1976, fl., E.P. Heringer 15333 (UNB).

Material adicional examinado: BRASIL. GOIÁS: Goiânia, estrada para Seminário Santa Cruz, 30.I.1969, fl., J.A. Rizzo \& A. Barbosa 3544 (UFG).

Habenaria obtusa está distribuída no Brasil pelos estados de Alagoas, Bahia, Distrito Federal, Goiás, Maranhão, Mato Grosso, Mato Grosso do Sul, Minas Gerais, Pará, Paraná, Paraíba, Pernambuco, Roraima, Sergipe, São Paulo e Tocantins, ocorrendo também na Colômbia, Equador, Guiana, Paraguai, Peru, Suriname e Venezuela (Batista et al. 2008; 
Barros et al. 2013). Espécie coletada em campos rupestres. Floresce em janeiro. Habenaria obtusa possui labelo inteiro, assim como Habenaria petalodes Lindl. (diferenciando-as das demais espécies do gênero ocorrentes na região), porém pode ser diferenciada desta pelas pétalas bipartidas com segmento superior triangular-lanceolado e segmento inferior reduzido a um pequeno dente.

21. Habenaria petalodes Lindl., Gen. Sp. Orchid. Pl. p. 316. 1835.

Fig. $3 \mathrm{j}$

Terrícola, 54-60 cm alt. Caule não intumescido em pseudobulbo. Folhas herbáceas, espiraladas ao longo do caule, a maior 8-9 × 2,5-3 $\mathrm{cm}$, decrescendo em direção ao ápice do caule, tornando-se brácteas gradativamente, lâminas lanceoladas, base amplexicaule, ápice agudo. Inflorescência em racemo, terminal, 17-25 cm compr., multiflora, ereta, sub-laxa. Flores verdes, pediceladas, calcaradas; cálcar 2,2-2,3 cm compr.; sépala dorsal ca. 8-9 $\times 7 \mathrm{~mm}$, ovada a largo-elíptica, ápice obtuso; sépalas laterais ca. 1,1-1,3 ×0,5 cm, subfalcadas, ápice agudo; pétalas 8-10 × 5-6 mm, inteiras, sub-quadrangulares, ápice truncado, dilatado; labelo ca. 1,6 $\times 0,3 \mathrm{~cm}$, inteiro, linear, revoluto, dilatado na base; ginostêmio ca. $3 \mathrm{~mm}$ compr.

Material examinado: PESCAN, 27.II.2008, fl., C.F. Hall et al. 526 (UFG).

Habenaria petalodes está distribuída, no Brasil, pelos estados de Alagoas, Bahia, Ceará, Distrito Federal, Espírito Santo, Goiás, Maranhão, Mato Grosso do Sul, Minas Gerais, Pará, Paraíba, Pernambuco, Rio de Janeiro, Sergipe e São Paulo, ocorrendo também no Paraguai (Batista et al. 2008). Conforme citado na literatura (Batista et al. 2004), $H$. petalodes consegue se adaptar a ambientes antropizados, tendo sido coletada na serapilheira em estrada que corta um fragmento de mata dentro do PESCAN. Espécie vista em flor, na área de estudo, entre fevereiro e março. Habenaria petalodes possui labelo inteiro, assim como H. obtusa, porém pode ser diferenciada desta pelas pétalas inteiras, subquadrangulares com ápice truncado.

22. Habenaria secundiflora Barb. Rodr., Gen. Sp. Orchid. 2: 252. 1882. Fig. 3k

Terrícola, $30-60 \mathrm{~cm}$ alt. Caule não intumescido em pseudobulbo. Folhas herbáceas, espiraladas ao longo do caule, a maior $6-13,5$ $\times 0,3-0,4 \mathrm{~cm}$, decrescendo em direção ao ápice do caule, tornando-se brácteas gradativamente, lâminas aciculares, base amplexicaule, ápice agudo.
Inflorescência em racemo, terminal, 9-10 cm compr., pauciflora, ereta, sub-laxa. Flores verdes, ressupinadas, pediceladas, calcaradas; cálcar ca. 1,3 cm compr.; sépala dorsal ca. $6 \times 4 \mathrm{~mm}$, ovada, ápice agudo a obtuso; sépalas laterais ca. $7 \times 2$ $\mathrm{mm}$, falciformes, ápice agudo; pétalas bipartidas, segmento superior ca. $5 \times 1 \mathrm{~mm}$, linear, ápice agudo, segmento inferior ca. $7 \times 1 \mathrm{~mm}$, linear, ápice agudo; labelo ca. $7 \mathrm{~mm}$ compr., tripartido, dilatado na base, segmento mediano ca. $5 \times 1 \mathrm{~mm}$, linear, ápice agudo; segmentos laterais ca. $7 \times 1 \mathrm{~mm}$, lineares, ápice agudo; ginostêmio ca. $2 \mathrm{~mm}$ compr. Material examinado: PESCAN, 27.II.2008, fl., C.F. Hall et al. 522 (UFG).

Habenaria secundiflora está distribuída, no Brasil, pelos estados de Amazonas, Distrito Federal, Goiás, Minas Gerais, Pará, Paraná e São Paulo, ocorrendo também na Colômbia, Guiana, Guiana Francesa e Venezuela (Batista et al. 2008). Espécie coletada em campos úmidos do PESCAN, e vista em flor entre janeiro e março. Dentre as espécies ocorrentes na região estudada, $H$. secundiflora possui grande semelhança $\operatorname{com} H$. leprieuri; as diferenças entre elas foram discutidas nos comentários desta última espécie.

23. Koellensteinia tricolor (Lindl.) Rchb. f., Ann. Bot. Syst. 6: 552. 1863.

Fig. 4a-b

Terrícola ou rupícola, $45-55 \mathrm{~cm}$ alt. Cauloma intumescido em pseudobulbo; pseudobulbos ca. $2 \mathrm{~cm}$ compr., piriformes, unifoliados. Folhas verde-escuras, subcoriáceas, plicadas, nervuras longitudinais proeminentes, $35-48 \times 3,5-4 \mathrm{~cm}$, oblanceoladas, ápice agudo. Inflorescência em racemo, lateral, $45-55 \mathrm{~cm}$ compr., multiflora, ereta, laxa. Flores alvas com máculas vinosas, ressupinadas, pediceladas, ecalcaradas; sépala dorsal alva, ca. $1,4-1,5 \times 0,8 \mathrm{~cm}$, elíptica, ápice arredondado; sépalas laterais alvas, ca. 1,4-1,5 × 0,8 $\mathrm{cm}$, elípticas, ápice arredondado; pétalas alvas com máculas vinosas, ca. 1,2-1,3 ×0,8 cm, elípticas, ápice arredondado; labelo alvo com máculas vinosas, ca. 0,7 $\times 1,1 \mathrm{~cm}$, trilobado, lobo mediano ca. $0,5 \times 1,1 \mathrm{~cm}$, reniforme, ápice arredondado, lobos laterais ca. $4 \times 5 \mathrm{~mm}$, suborbiculares; ginostêmio alvo, ca. $4 \mathrm{~mm}$ compr.

Material examinado: PESCAN, 27.II.2008, fl. fr., C.F. Hall et al. 523 (UFG).

Koellensteinia tricolor está distribuída, no Brasil, pelos estados do Amapá, Distrito Federal, Goiás, Minas Gerais, Paraná, Roraima, ocorrendo também na Guiana, Peru e Venezuela (Barros et al. 


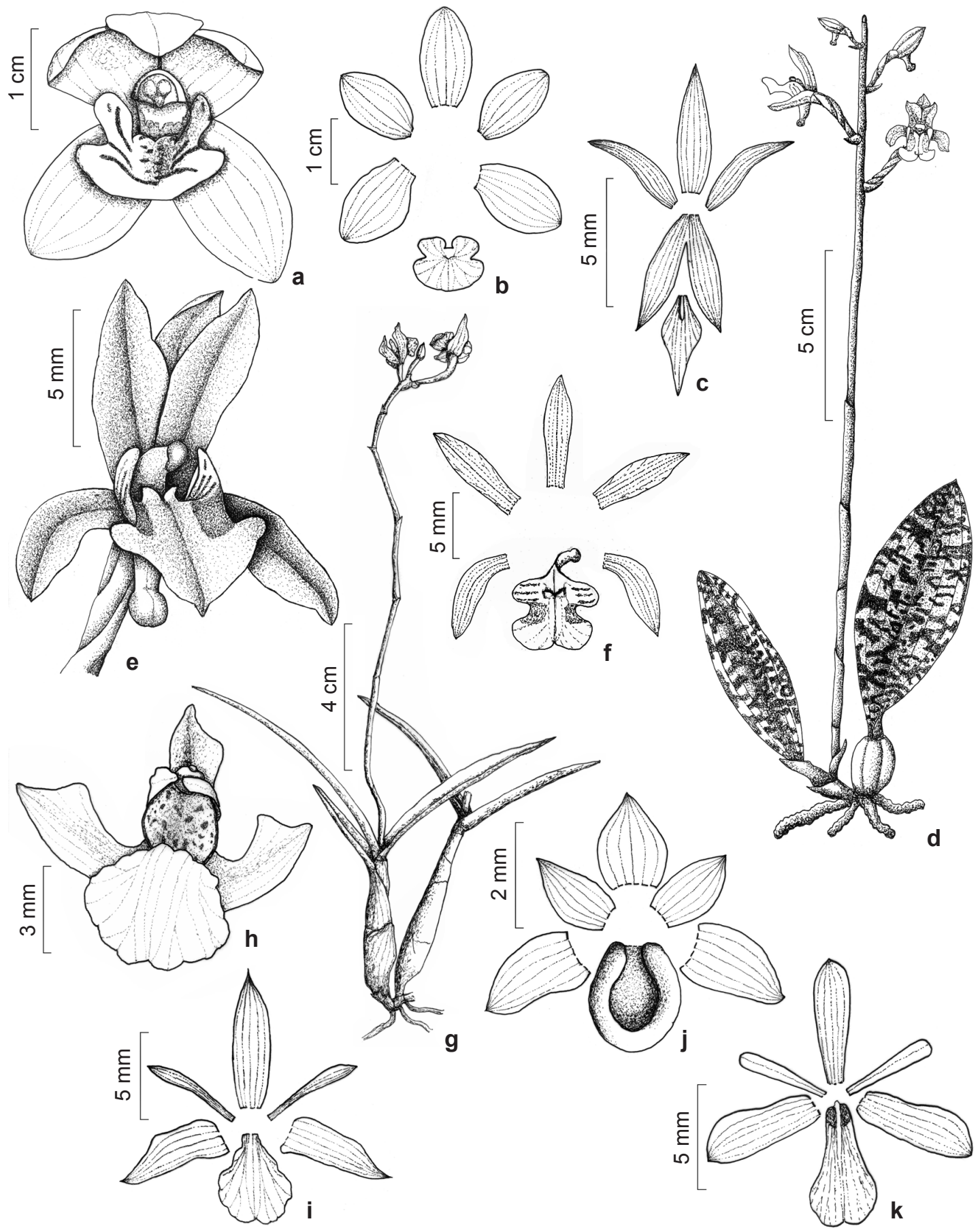

Figura 4 - a-b. Koellensteinia tricolor - a. vista frontal da flor; b. peças florais. c. peças florais de Notylia hemitricha. d-f. Oeceoclades maculata - d. hábito; e. flor; f. peças florais. g-i. Orleanesia mineirosensis - g. hábito; h. vista frontal da flor; i. peças florais. j. peças florais de Prescottia oligantha. k. peças florais de Scaphyglottis prolifera. (a-b C.F. Hall et al. 523; c T.B. Cavalcanti et al. 1967; d-e material vivo; f C.F. Hall et al. 283; g-h material vivo; i G.P. Silva et al. 3604; j T.B. Cavalcanti et al. 1977; k T.A.B. Dias et al. 341).

Figure 4 - a-b. Koellensteinia tricolor - a. flower front view; b. floral parts. c. floral parts of Notylia hemitricha. d-f. Oeceoclades maculata - d. habit; e. flower front view; f. floral parts. g-i. Orleanesia mineirosensis - g. habit; h. flower; i. floral parts. j. floral parts of Prescottia oligantha. k. floral parts of Scaphyglottis prolifera. (a-b C.F. Hall et al. 523; c T.B. Cavalcanti et al. 1967; d-e live material; f C.F. Hall et al. 283; g-h live material; i G.P. Silva et al. 3604; j T.B. Cavalcanti et al. 1977; k T.A.B. Dias et al. 341). 
2013; World Checklist of Monocotyledons 2012). Espécie coletada em campos rupestres, margeando corpos d'água no PESCAN e vista em flor entre os meses de dezembro e fevereiro. Ao contrário do que ocorre na maior parte das localidades onde foi registrada, nas quais ocorre em áreas com vegetação aberta, uma pequena população de $K$. tricolor foi encontrada dentro de mata de galeria no PESCAN. Koellensteinia tricolor pode ser diferenciada das outras espécies de orquídeas ocorrentes na região estudada por suas flores alvas com máculas vinosas nas pétalas e no labelo e por suas longas folhas plicadas quase do mesmo comprimento da inflorescência.

24. Notylia hemitricha Barb. Rodr., Gen. Spec. Orchid. 2: 223. 1882. Fig. 4c

Epífita, 13-21 cm alt. Cauloma intumescido em pseudobulbo; pseudobulbos 1,2-1,5 cm compr., piriformes, transversalmente arredondados, unifoliados. Folhas verdes, cartáceas, conduplicadas, 2,4-4,3 ×0,7-1,4 cm, elípticas a estreito-elípticas, ápice obtuso. Inflorescência em racemo, lateral, 13$21 \mathrm{~cm}$ compr., multiflora, pendente, congesta. Flores verdes com máculas alaranjadas, ressupinadas, pediceladas, ecalcaradas; sépala dorsal ca. $5 \times 1,5-2$ $\mathrm{mm}$, lanceolada, ápice obtuso; sépalas laterais livres entre si ou coalescentes na base, ca. $4 \times 1 \mathrm{~mm}$, oblongo-obovadas, ápice agudo; pétalas ca. 4,5 $\times$ $0,5 \mathrm{~mm}$, lanceoladas, ápice agudo; labelo ca. $4 \times$ 2-2,5 mm, ovado, carenado na base, ápice agudo; ginostêmio ca. $2 \mathrm{~mm}$ compr.

Material examinado: margem do Rio Corumbá, 22. IX.1993, fl., G.P. Silva et al. 1923 (CEN); 11.VI.1996, fl., T.B. Cavalcanti et al. 1967 (CEN).

Notylia hemitricha está distribuída pela Bahia, Distrito Federal, Espírito Santo, Goiás Mato Grosso, Paraná, Pernambuco, Rio de Janeiro, Rio Grande do Sul, Santa Catarina e São Paulo (Barros et al. 2013). Espécie coletada em matas de galeria próximas ao Rio Corumbá. Floresce entre os meses de junho e setembro. Notylia hemitricha pode ser diferenciada das outras espécies de orquídeas ocorrentes na região estudada por sua inflorescência em racemo pendente, com várias pequenas flores verdes com máculas alaranjadas.

25. Oeceoclades maculata (Lindl.) Lindl., Gen. Sp. Orchid. Pl. p. 237. $1833 . \quad$ Fig. 4d-f

Terrícola, ca. $20 \mathrm{~cm}$ alt. Cauloma intumescido em pseudobulbo; pseudobulbos ca. $2 \mathrm{~cm}$ compr., piriformes, unifoliados. Folhas verdeclaras maculadas de verde-escuro, coriáceas, conduplicadas, com apenas a nervura central proeminente, $8-9 \times 2-3 \mathrm{~cm}$, elípticas, ápice agudo. Inflorescência em racemo, lateral, ca. 20 cm compr., pauciflora, ereta, laxa. Flores cremeesverdeadas, ressupinadas, pediceladas, calcaradas; cálcar ca. $4 \mathrm{~mm}$ compr., cilíndrico, ápice clavado; sépala dorsal ca. 8-9 × $2 \mathrm{~mm}$, oblanceolada, côncava, ápice agudo; sépalas laterais ca. 7-8 $\times 2$ $\mathrm{mm}$, oblanceoladas, falcadas, ápice agudo; pétalas ca. 7-8 $\times 3 \mathrm{~mm}$, estreito-elípticas a oblanceoladas, ápice agudo; labelo alvo com máculas róseas, ca. $7 \times 8 \mathrm{~mm}$, trilobado, lobo mediano ca. $4 \times 6 \mathrm{~mm}$, bilobado, lobos laterais ca. $2 \times 3 \mathrm{~mm}$, arredondados; ginostêmio alvo, ca. $5 \mathrm{~mm}$ compr.

Material examinado: PESCAN, 27.II.2008, fr., C.F. Hall et al. 524 (UFG).

Material adicional examinado: BRASIL. GOIÁS: Serra dos Pireneus, 26.II.2007, fl. e fr., C.F. Hall et al. 283 (UFG).

Oeceoclades maculata possui ampla distribuição ocorrendo por toda a África tropical e nas Américas, desde a Flórida ao Paraguai, incluindo o Brasil, do Amazonas ao Rio Grande do Sul (Stern 1988). Espécie coletada no interior de matas de galeria do PESCAN, onde floresceu em fevereiro. A ampla distribuição de $O$. maculata, incluindo mais de um continente, é incomum entre as Orchidaceae e mesmo entre as demais espécies do gênero. Oeceoclades maculata pode ser facilmente diferenciada das outras espécies de orquídeas ocorrentes na região estudada por suas folhas verde-claras, maculadas de verde-escuro, característica relativamente rara entre as orquídeas.

26. Orleanesia mineirosensis Garay, Bradea 1: 303. 1973.

Fig. 4g-i

Epífita, 15,5-56,5 $\mathrm{cm}$ alt. Cauloma intumescido em pseudobulbo; pseudobulbos 5,5-9 cm compr., fusiformes, multifoliados. Folhas coriáceas, dísticas, $3,3-7,1 \times 0,3-0,5 \mathrm{~cm}$, lineares, ápice agudo. Inflorescência em racemo ou panícula pauciramosa, terminal, $10-47,5 \mathrm{~cm}$ compr., multiflora, ereta, laxa. Flores voltadas para cima, ressupinadas, pediceladas, ecalcaradas; sépala dorsal creme-esverdeada, 7,5-9 × 2,5-3 mm, ovada, ápice acuminado; sépalas laterais cremeesverdeadas, ca. 6-8 × $3 \mathrm{~mm}$, ovadas, falcadas, ápice acuminado; pétalas creme-esverdeadas, ca. 6-6,5 × $1 \mathrm{~mm}$, oblanceoladas, ápice agudo; labelo alvo-esverdeado, não adnato ao ginostêmio, ca. $7 \times 5$ $\mathrm{mm}$, inteiro, obovado, ápice emarginado; ginostêmio alvo com grande mácula amarela e pequenas máculas vinosas na face ventral, ca. $4 \mathrm{~mm}$ compr. 
Material examinado: 11.XII.1996, fl., S.P. CordovilSilva et al. 530 (CEN); Ponte de São Bento, 29.VIII.1996, fl., G.P. Silva et al. 3604 (CEN).

Orleanesia mineirosensis é endêmica do estado de Goiás (Barros et al. 2013). Espécie coletada em campos rupestres e matas de galeria. Floresce entre agosto e dezembro. Orleanesia mineirosensis pode ser diferenciada das outras espécies de orquídeas ocorrentes na região estudada pela inflorescência terminal portando flores voltadas para cima, com sépalas e pétalas creme-esverdeadas.

27. Prescottia oligantha (Sw.) Lindl., Gen. Sp. Orchid. Pl. p. 455. 1830.

Fig. 4j

Terrícola, ca. $38 \mathrm{~cm}$ alt. Raízes carnosas, pilosas. Caule não intumescido em pseudobulbo. Folhas herbáceas, basais, rosuladas, 5,5-6 $\times$ 2,1-2,8 cm, largo-elípticas a ovadas, base atenuada em pseudopecíolo, ápice agudo. Inflorescência em espiga, terminal, ca. $38 \mathrm{~cm}$ compr., multiflora, ereta, congesta. Flores alvas com margens vináceas, não ressupinadas, sésseis, ecalcaradas; sépala dorsal ca. 1,5 × $1 \mathrm{~mm}$, ovada, revoluta, ápice agudo; sépalas laterais ca. $2 \times 1,5 \mathrm{~mm}$, ovadas, revolutas, ápice arredondado; pétalas ca. 1,2 ×0,7 mm, ovadas, revolutas, ápice agudo; labelo alvo, internamente piloso, ca. $2 \times 2 \mathrm{~mm}$, inteiro, largo-ovado, calceolado, ápice obtuso; ginostêmio ca. $1 \mathrm{~mm}$ compr.

Material examinado: próximo ao Rio Corumbá, 11.VI.1996, fl., T.B. Cavalcanti et al. 1977 (CEN).

Prescottia oligantha está distribuída desde os Estados Unidos até a Argentina. No Brasil, ocorre em Alagoas, Bahia, Distrito Federal, Espírito Santo, Goiás, Mato Grosso do Sul, Minas Gerais, Paraná, Pernambuco, Rio de Janeiro, Rio Grande do Sul, Roraima, Santa Catarina e São Paulo (Azevedo 2009). Espécie coletada em fendas de rocha próximas ao Rio Corumbá. Floresce em junho. Prescottia oligantha pode ser diferenciada das outras espécies de orquídeas ocorrentes na região estudada pelas flores sésseis, não ressupinadas, com labelo calceolado.

28. Scaphyglottis prolifera (R.Br.) Cogn. In: C.F.P. von Martius \& auct. suc. (eds.), Fl. bras. 3(5): 15. 1898.

Fig. $4 \mathrm{k}$

Epífita, pendente, 8,6-10,3 cm alt. Cauloma intumescido em pseudobulbo; pseudobulbos sobrepostos, ca. $5 \mathrm{~cm}$ compr., cilíndricos a fusiformes, bifoliados. Folhas cartáceas, 2-4,7 $\times$ 0,3-0,4 cm, linear-elípticas, ápice arredondado a retuso. Inflorescência em fascículo, terminal, 7-9 $\mathrm{mm}$ compr., pauciflora, congesta. Flores creme, ressupinadas, pediceladas, ecalcaradas; sépala dorsal ca. $6 \times 2 \mathrm{~mm}$, oblanceolada, ápice obtuso; sépalas laterais ca. 5-6 × 2,5 mm, oblongoobovadas, ápice arredondado; pétalas ca. $5 \times 1 \mathrm{~mm}$, estreito-oblanceoladas, ápice arredondado; labelo ca. $6 \times 3 \mathrm{~mm}$, inteiro, obovado, ápice emarginado; ginostêmio ca. $5 \mathrm{~mm}$ compr.

Material examinado: 11.XII.1996, fl., S.P. CordovilSilva et al. 528 (CEN); próximo ao Rio Corumbá, 10.II.1993, fl., T.A.B. Dias et al. 341 (CEN).

Scaphyglottis prolifera está distribuída desde o México até o Brasil. No Brasil, está presente no Amazonas, Distrito Federal, Espírito Santo, Goiás, Mato Grosso, Minas Gerais, Pará e Rio de Janeiro (Barros et al. 2013; World Checklist of Monocotyledons 2012). Espécie coletada em matas, cerrado sensu stricto e campos rupestres. Floresce entre os meses de dezembro e fevereiro. Scaphyglottis prolifera pode ser diferenciada das outras espécies de orquídeas ocorrentes na região estudada pelos pseudobulbos sobrepostos, ou seja, os novos pseudobulbos crescem no ápice do anterior.

\section{Agradecimentos}

À Fundação de Apoio a Pesquisa da Universidade Federal de Goiás (FUNAPE-UFG), a bolsa concedida ao primeiro autor, através de fundos concedidos pela Anglo American Brasil; ao Conselho Nacional de Desenvolvimento Científico e Tecnológico (CNPq), a bolsa de produtividade em pesquisa concedida ao terceiro autor; a todos que auxiliaram nos trabalhos de campo, especialmente Augusto Francener Nogueira Gonzaga e Caroline de Oliveira Martins; à Agência Ambiental do Estado de Goiás, a autorização para a realização do trabalho; à diretoria e funcionários do PESCAN, o alojamento e informações sobre o parque; aos curadores dos herbários CEN, IBGE, SP, UB e UFG, o acesso às suas coleções; ao Laboratório de Morfologia e Taxonomia Vegetal da Universidade Federal de Goiás pelo material de campo e infraestrutura. Esse estudo é parte da dissertação de mestrado do primeiro autor, no Programa de Pós-Graduação em Ecologia e Evolução da Universidade Federal de Goiás.

\section{Referências}

Azevedo, C.O. 2009. Filogenia e revisão taxonômica do gênero Prescottia Lindl. (Orchidaceae Orchidoideae). Tese de Doutorado. Universidade Estadual de Feira de Santana, Feira de Santana. 301p. 
Barros, F.; Vinhos, F.; Rodrigues, V.T.; Barberena, F.F.V.A.; Fraga, C.N.; Pessoa, E.M.; Forster, W. 2013. Orchidaceae. In: Lista de espécies da flora do Brasil. Jardim Botânico do Rio de Janeiro. Disponível em <http://floradobrasil.jbrj.gov.br/ jabot/floradobrasil/FB179>. Acesso em 18 Mai 2013.

Batista, J.A.N. \& Bianchetti, L.B. 2002. A review of Habenaria (Orchidaceae) in Pabst and Dungs' Orchidaceae Brasilienses. Lindleyana 17: 75-84.

Batista, J.A.N. \& Bianchetti, L.B. 2003. Lista atualizada das Orchidaceae do Distrito Federal. Acta Botanica Brasilica 17: 183-201.

Batista, J.A.N.; Bianchetti, L.B.; González-Tamayo, R.; Figueroa, X.M.C. \& Cribb, P.J. 2011. A synopsis of new world Habenaria (Orchidaceae) I. Harvard Papers in Botany 16: 1-47.

Batista, J.A.N.; Bianchetti, L.B.; Nogueira, R.E.; Pellizzaro, K.F. \& Ferreira, F.E. 2004. The genus Habenaria (Orchidaceae) in the Itacolomi State Park, Minas Gerais, Brazil. Sitientibus série Ciências Biológicas 4: 25-36.

Batista, J.A.N.; Bianchetti, L.B. \& Pellizzaro, K.F. 2005. Orchidaceae da Reserva Ecológica do Guará, DF, Brasil. Acta Botanica Brasilica 19: 221-232.

Batista, J.A.N.; Silva, J.B.F. \& Bianchetti, L.B. 2008. The genus Habenaria (Orchidaceae) in the Brazilian Amazon. Revista Brasileira de Botânica 31: 105-134.

Bianchetti, L.B.; Batista, J.A.N.; Pellizzaro, K.F. \& Augusto, M.M. 2005. Família Orchidaceae na APA de Cafuringa. In: Netto, P.B.; Mecenas, V.V. \& Cardoso, E.S. (eds.). APA de Cafuringa: a última fronteira natural do DF. Secretaria de Meio Ambiente e Recursos Hídricos, Brasília. Pp. 153-163.

Cogniaux, A. 1893-1896. Orchidaceae. In: Martius, C.F.P.; Eichler, A.G. \& Urban, I. (eds.). Flora brasiliensis. Vol. 3, n. 4. Monachii, Typographia Regia. Pp. 1-672.

Cogniaux, A. 1898-1902. Orchidaceae. In: Martius, C.F.P.; Eichler, A.G. \& Urban, I. (eds.). Flora brasiliensis. Vol. 3, n. 5. Monachii, Typographia Regia. Pp. 1-664.

Cogniaux, A. 1904-1906. Orchidaceae. In: Martius, C.F.P.; Eichler, A.G. \& Urban, I. (eds.). Flora brasiliensis. Vol. 3, n. 6. Monachii, Typographia Regia. Pp. 1-604.

Dias, B.F.D.S. 1992. Alternativas de desenvolvimento dos Cerrados: manejo e conservação dos recursos naturais renováveis. UnB/Ibama/Funatura, Brasília. 97p.

Filgueiras, T.S. \& Pereira, B.A.S. 1994. Flora do Distrito Federal: Orchidaceae. In: Pinto, M.N. (org.). Cerrado: caracterização, ocupação e perspectivas. $2^{\text {a }}$ ed.UnB/SEMATEC, Brasília. Pp. 391-393.

Hoehne, F.C. 1940. Orchidaceas. In: Hoehne, F.C. (ed.). Flora Brasilica. Vol. 12, n. 1. Secretaria da
Agricultura, Indústria e Comércio de São Paulo, São Paulo. Pp. 1-254.

Hoehne, F.C. 1942. Orchidaceas. In: Hoehne, F.C. (ed.). Flora Brasilica. Vol. 12, n. 6. Secretaria da Agricultura, Indústria e Comércio de São Paulo, São Paulo. Pp. 1-218.

Hoehne, F.C. 1945. Orchidaceas. In: Hoehne, F.C. (ed.). Flora Brasilica. Vol. 12, n. 2. Secretaria da Agricultura, Indústria e Comércio de São Paulo, São Paulo. Pp. 1-389.

Hoehne, F.C. 1949. Iconografia das Orchidaceas do Brasil. Secretaria da Agricultura, São Paulo. 601p.

Hoehne, F.C. 1953. Orchidaceas. In: Hoehne, F.C. (ed.). Flora Brasilica. Vol. 12, n. 7. Secretaria da Agricultura, Indústria e Comércio de São Paulo, São Paulo. Pp. 1-397.

Iglesias, J.O.V.; Junqueira, D.I.; Rando, J.G. \& Moura, T.M. 2011. Listagem das Leguminosae Caesalpinioideae no Parque Estadual da Serra de Caldas Novas, Goiás, Brasil. Revista Brasileira de Biociências 9: 421-427.

Klink, C.A. \& Machado, R.B.A. 2005. Conservação do Cerrado brasileiro. Megadiversidade 1: 147-155.

Köppen, W. 1948. Climatologia: com um estúdio de los climas de la terra. Fondo de Cultura Econômica, Pánuco. 478p.

Lima, T.A.; Pinto, J.R.R.; Lenza, E. \& Pinto, A.S. 2010. Floristic and structure of woody vegetation of a "cerrado rupestre" area in Serra de Caldas Novas State Park, Goiás. Biota Neotropica 10: 159-166.

Meneguzzo, T.E.C.; Bianchetti, L.B. \& Proença, C.E.B. 2012. O gênero Encyclia (Orchidaceae) no Distrito Federal, Goiás e Tocantins. Rodriguésia 63: 277-292.

Menezes, L.C. 2000. Genus Cyrtopodium: Brazilian species. IBAMA, Brasília. 208p.

Mori, S.A.; Silva, L.A.M.; Lisboa, G. \& Coradin, L. 1989. Manual de manejo do herbário fanerogâmico. $2^{\text {a }}$ ed. CEPLAC, Ilhéus. 104p.

Myers, N.; Mittermeier, R.A.; Mittermeier, C.G.; Fonseca, G.A.B. \& Kent, J. 2000. Biodiversity hotspots for conservation priorities. Nature 403: 853-858.

Pabst, J.F.G. \& Dungs, F. 1975. Orchidaceae Brasilienses. Vol. 1. Hildesheim, Kurt Schmersow. 408p.

Pabst, J.F.G. \& Dungs, F. 1977. Orchidaceae Brasilienses. Vol. 2. Hildesheim, Kurt Schmersow. 418p.

Pansarin, E.R. 2005. Sistemática filogenética e biologia floral de Pogoniinae sul-americanas, e revisão taxonômica e análise das ceras epicuticulares do gênero Cleistes Rich. ex Lindl. (Orchidaceae). Tese de Doutorado. Universidade Estadual de Campinas, Campinas. 195p.

Pereira, B.A.S.; Silva, M.A. \& Mendonça, R.C. 1993. Reserva Ecológica do IBGE, Brasília (DF): lista das plantas vasculares. IBGE, Rio de Janeiro. 43p. 
Rizzo, J.A. 1981. Flora do estado de Goiás - coleção Rizzo/Plano de Coleção (Fanerogámas). Ed. Universidade Federal de Goiás, Goiânia. 35p.

Rodrigues, J.B. 1877. Genera et Species Orchidearum Novarum. Vol. 1. Typographia Nacional, Rio de Janeiro. 206p.

Rodrigues, J.B. 1882. Genera et Species Orchidearum Novarum. Vol. 2. Typographia Nacional, Rio de Janeiro. 295p.

Romero-González, G.A.; Batista, J.A.N. \& Bianchetti, L.B.A. 2008. Synopsis of the genus Cyrtopodium (Catasetinae: Orchidaceae). Harvard Papers in Botany 13: 189-206.

SIEG - Sistema Estadual de Estatística e de Informações Geográficas de Goiás. 2012. Disponível em $<$ http:// www.sieg.go.gov.br/viewcade.asp?id_cade $=9>$. Acesso 19 Set 2012.

Silva, L.O.; Costa, D.A.; Filho, K.E.S.; Ferreira, H.D. \& Brandão, D. 2002. Levantamento florístico e fitossociológico em duas áreas de cerrado sensu stricto no Parque Estadual da Serra de Caldas Novas, Goiás. Acta Botanica Brasilica 16: 43-53.
Smidt, E.C. 2007. Filogenia e revisão taxonômica de Bulbophyllum Thouars (Orchidaceae) ocorrentes no neotrópico. Tese de Doutorado. Universidade Estadual de Feira de Santana, Feira de Santana. $346 \mathrm{p}$.

Sprunger, S. 1996. João Barbosa Rodrigues - Iconographie des orchidées du Brésil. Vol. 1. The illustrations. Friedrich Reinhardt Verlag, Basle. 540p.

Stancik, J.F.; Goldenberg, R. \& Barros, F. 2009. O gênero Epidendrum L. (Orchidaceae) no estado do Paraná, Brasil. Acta Botanica Brasilica 23: 864-880.

Stern, W.L. 1988. The long-distance dispersal of Oeceoclades maculata. American Orchid Society Bulletin 57: 960-971.

Thiers, B. 2013. Index Herbariorum: A global directory of public herbaria and associated staff. New York Botanical Garden's Virtual Herbarium. Disponível em http://sweetgum.nybg.org/ih/. Acesso em 25 Mai 2013.

World Checklist of Monocotyledons. 2012. Disponível em <http://apps.kew.org/wcsp/home.do $>$. Acesso em 1 Jul 2012. 